\title{
Assessment and source identification of heavy metal contamination of groundwater using geospatial technology in Gadilam River basin, Tamil Nadu, India
}

\author{
K. Mohammed Rizwan ${ }^{1} \cdot$ V. Thirukumaran ${ }^{1} \mathbb{D} \cdot$ M. Suresh ${ }^{2}$
}

Received: 9 December 2020 / Accepted: 25 May 2021 / Published online: 2 June 2021

(c) The Author(s) 2021

\begin{abstract}
The purpose of this study is to determine the groundwater quality of the Gadilam River basin on the basis of Geographic Information Technology (GIS) taxonomy evaluation and risk assessment and statistical analysis. The Gadilam River originates from the district of Kallakurichi and flows into the district of Viluppuram finally confluence at Bay of Bengal in the district of Cuddalore. Groundwater supplies are serving the entire drinking needs of the residents of the Gadilam River basin, and pollution of its toxic elements has been raised in recent years. A total of 120 groundwater samples, excluding reserved forest areas, were obtained from the Gadilam River basin. 50 samples of the Archaean formation, 34 samples of the Quaternary formation, 35 additional Tertiary formation samples and one Cretaceous formation sample. During the monsoon season (Nov. 2018), groundwater samples were taken, which is after the Gaja cyclone's diastral effects. At the time of the sample acquisition, $\mathrm{pH}, \mathrm{EC}$ and TDS were measured using the Elico field kit. Using the Atomic Absorption Spectrometer, the heavy metals $\mathrm{Zn}, \mathrm{Cr}, \mathrm{Cu}, \mathrm{Pb}, \mathrm{Co}, \mathrm{Fe}, \mathrm{Mn}$ and $\mathrm{Ni}$ were analyzed. The spatial distribution maps of the GIS shows that in all the samples the concentrations of chromium, lead, cobalt, nickel are high (above the permitted limit). In 93.40\%of the area, the manganese concentrations are higher, dropping under the unauthorized cap for human use in compliance with WHO requirements. In addition, statistical analysis indicates that groundwater pollution of the roots of $\mathrm{Pb}$ and $\mathrm{Cr}$ is from foreign sources and geogenic origin cannot be avoided. The country's rocks and industrial effluents can trigger $\mathrm{Zn}$ and $\mathrm{Co}$. The anthropogenic operations may be due to $\mathrm{Cu}$. The taxonomy diagram showing all groundwater samples is classified as 'near neutral high metal.' Industrial waste, household sewage, has boosted the emission of heavy metals. Groundwater risk assessment study of heavy metals using SMCE approach reveals that dense residential area in the Archaean formation, lineaments intersection with river portion and sea shore area in Quaternary formation and nearby SIPCOT industry and Lignite mining area in Tertiary formation is noted in the 'Extreme risk dangerous' areas.
\end{abstract}

Keywords Groundwater contamination · Gaja cyclone $\cdot$ Heavy metals risk assessment $\cdot$ Taxonomy assessment

\section{Introduction}

Heavy metal groundwater toxicity is one of the most significant organic concerns on the globe (Abou Zakhem and Hafez 2015; Yousefi et al. 2018; Rezaei et al. 2019; Huzefa Shaikh et al. 2020). Groundwater, which is highly vulnerable

V. Thirukumaran

geogacslm7@gmail.com

1 Department of Geology, Government Arts College (Auto), Salem, Tamil Nadu 636007, India

2 Jayalakshmi Institute of Technology, Thoppur, Dharmapuri, Tamil Nadu 636352, India to pollution from industrial and farming operations, is the most appropriate and widely used source of drinking water (Krishna and Mohan 2016; Yang et al. 2020). The natural disintegration of water is a growing environmental concern in the world (Pathak et al. 2015; Pobi et al. 2017 2019; Mahapatra et al. 2020).

The micronutrients much required for the functioning and digestion of life, constitute the dissolved trace elements. However, it becomes poisonous when these dissolved elements surpass the quantity needed by these species. Heavy metals are also harmful to the human body, causing many illnesses by the effects of aggregation (Bhuiyan et al. 2010; Kumar et al. 2021; Ogbomida et al. 2018; Ravindra and Mor 2019). Heavy metals in aquatic 
habitats have risen dramatically since the beginning of the industrial revolution (Severini et al. 2018). Heavy metals are higher than usual groundwater conditions in heavily urbanized and industrialized areas (Rai 2008; Antoniadis et al. 2017; Asghari et al. 2018; Qasemi et al. 2019; Noah and Anthony, 2020).

Groundwater contamination has risen exponentially in recent decades due to dissolved rock salts and toxic waste (Islam et al. 2018). Panigrahy et al. 2015; Muthusaravanan et al. 2018; Adimalla 2019). In a quick face, the groundwater becomes a primary source for drinking, irrigation and industrialization purposes and hence its demand is increased. Panthri and Gupta 2019 identified patches of groundwater deterioration due to heavy metal industrial and domestic effluent.

The issues get severe where natural contaminations are intensified by anthropogenic exercises (Kupwade et al. 2013; Kumar 2014; Krishna and Mohan 2016; Wang et al. 2017; Alsbou and Al-Khashman 2018; Yang et al. 2020). (Kupwade et al. 2013; Kumar 2014; Krishna and Mohan 2016; Wang et al. 2017; Alsbou and Al-Khashman 2018; Yang et al. 2020). The pollution of groundwater is primarily caused by the drainage of mechanical effluents into nearby rivers, waterways, ponds, wetlands, dumps and open fields or agricultural lands. (Vijay et al. 2011; Banerjee and Gupta 2013; Tiwari et al. 2015; Saleh et al. 2018).

Latest literature on groundwater heavy metal concentrations has been performed in various locations in India with Adhikary et al. 2010; Xie et al 2011.; Haloi and Sarma 2012; Purushotham et al. 2013; Singaraja et al. 2015; Selvam et al. 2015b; Selvam et al. 2016; Selvam et al. 2017; Venkatramanan et al. 2014; Muhammad and Nafees 2018; Rostami et al. 2019; Huzefa Shaikh et al. 2020; Mahapatra et al. 2020; Ravindra et al. 2019; Noah and Anthony 2020.

Statistical methods, especially multivariate techniques, are a more accurate scientific approach to the data analysis of environmental quality evaluation conditions and can be useful for interpreting multiple elements (Zamani et al. 2015;). On the other hand, Geostatistic is an effective interpolation method that can measure and reduce sampling uncertainty, simplify source detection, while minimizing the expense of investigation (Wu et al. 2016; Rostami et al. 2019).

The basin catchment area is situated in the district of Kallakurichi, the mature stage of the flows of the river basin in the district of Viluppuram and the lower river basin in the districts of Cuddalore. Groundwater supplies are serving the entire drinking needs of the residents of the Gadilam River basin, and pollution of its radioactive elements has been raised in recent years. Therefore, in recent years, knowledge of groundwater quality characteristics in the research area has not been attempted. In the present research work, however, the main emphasis is on risk management and the detection by geospatial technologies of heavy metal pollution.

\section{Study area}

The Gadilam River originates from Kallakurichi district and flowing on Viluppuram district confluent the Bay of Bengal sea at Cuddalore district. This river total flow length is $102 \mathrm{~km}$ and area is $2091.20 \mathrm{sq} . \mathrm{km}$. It is reported that the river gets a supply of occasional floodwater from the Ponnaiyar River through the Malattar River. The Gadilam River basin is extending from $11^{\circ} 26^{\prime} 31.797^{\prime \prime}$ $\mathrm{N}$ to $11^{\circ} 56^{\prime} 29.633^{\prime \prime} \mathrm{N}$ latitudes and $78^{\circ} 59^{\prime} 10.675^{\prime \prime} \mathrm{E}$ to 7947'15.793" E longitudes (Fig. 1).

It covers in a portion of survey of India topographical maps $58 \mathrm{I} / 13,58 \mathrm{M} / 1,58 \mathrm{M} / 2,58 \mathrm{M} / 5,58 \mathrm{M} / 6,58 \mathrm{M} / 7$, $58 \mathrm{M} / 9,58 \mathrm{M} / 10,58 \mathrm{M} / 11$ and $58 \mathrm{M} / 15$ on scale of 1:50,000. The study area is surrounded by Villupuram in the north, Cuddalore town in east, Thirukoilur in west, and Vadalur in south. There are number (1024) of tanks is present in the study area of which, the major (Above 0.5 sq.km) 62 tanks are noted. Temperature is maximum during April and May 38 to $39{ }^{\circ} \mathrm{C}$, minimum in January and February 24 to $25^{\circ} \mathrm{C}$. The wind velocity is highest during summer and sometimes during monsoon seasons.

The Gadilam River basin consists of both hard rock and sedimentary rock formations. Nearly $66 \%$ occupied by Quaternary, Tertiary, Cretaceous formation of sedimentary rocks. It is located in the eastern part of the basin. 34\% of the basin underline by Archaean rock formation. The Archaean rocks such as Hornblende-biotite gneiss, Fissile hornblende gneiss, Gingee granite, Ultrabasic Rocks occur on the western part of the basin.

Two sets of lineaments are observed in the hard rock region of the study area where most are trending NE-SW and NW-SE directions. Majority of the lineaments were noticed in sedimentary region is N-S and NNE-SSW direction. The geology and major lineaments of the study area are shown in Fig. 1.

\section{Methodology}

Gadilam River base boundary demarcated based on the drainage system using Survey of India topographical maps $58 \mathrm{I} / 13,58 \mathrm{M} / 1,58 \mathrm{M} / 2,58 \mathrm{M} / 5,58 \mathrm{M} / 6,58 \mathrm{M} / 7,58 \mathrm{M} / 9$, $58 \mathrm{M} / 10,58 \mathrm{M} / 11$ and $58 \mathrm{M} / 15$ on 1:50,000 scale and drainage updating in current satellite data. Land use/land cover and lineaments prepared from Landsat- 8 TM data (March2018). Geology map is tracing from district resources map. The Gadilam River upper basin shows Archaean formation and lower basin shows Tertiary uplands in the south and recent alluvium (Quaternary) in the north (Fig. 1).

For the collection of 120 groundwater samples from the Gadilam River basin, except the reserved forest region, 

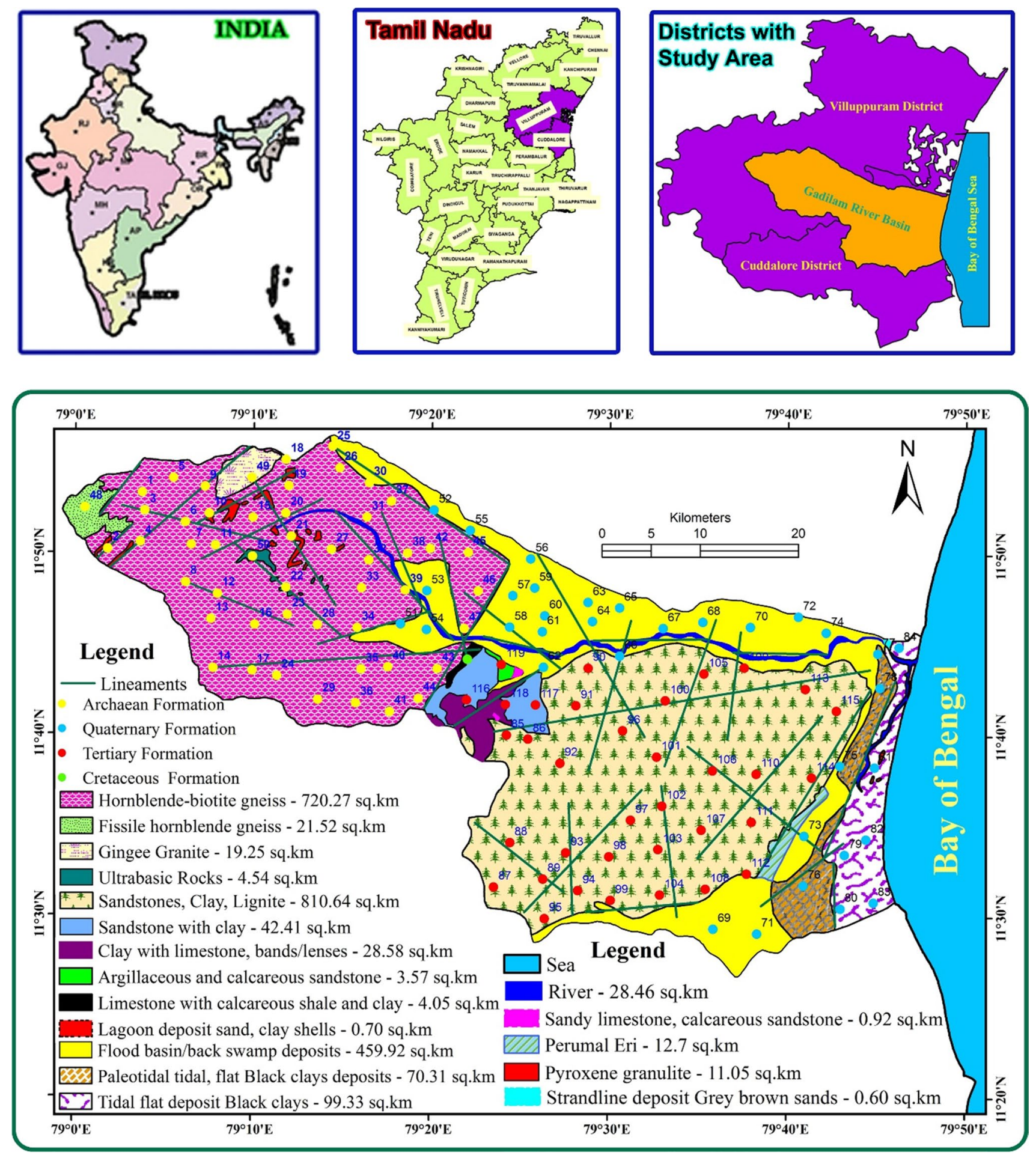

Fig. 1 Key map of present study

the systemic random approach is implemented with predetermined locations (Rahman et al. 2012; Selvam et al. 2018). Figure 1 indicates the distribution of 50 samples from the Archaean formation collected (Hornblende-biotite gneiss, Fissile hornblende gneiss, Gingee Granite and
Ultrabasic Rocks), 34 from Quaternary formation samples (Flood Basin/Back Marsh Deposits, Paleo-tidal flat Black Clays, Tidal Flat Black Clays deposits) and 35 more Tertiary Formation Samples (Sandstones, Clay, Lignite, Sandstone with clay, Argillaceous). One sample is from 
the Cretaceous formation. To ensure the collection of representative groundwater samples from each groundwater borehole and dug-wells Samples were obtained using 1-L plastic containers that were acid-washed. Groundwater samples were obtained during the monsoon season (November 2018), following the devastating North Indian Ocean Gaja cyclone in 2018.

The guidelines outlined by (APHA 2012) are followed during the sampling, planning and study. The bottles were cleaned with water to be sampled before the samples are taken. Before the start of the study, a few drops of heavy HNO3 acid were applied to the water sample to decrease the $\mathrm{pH} \sim 2$ and to avoid the precipitation of essential metals. Fifty milliliters of water was taken in a conical flask to prepare the samples for analysis; $10 \mathrm{ml}$ of concentrated HNO3 acid solution was applied and heated to a hot plate for digestion. This was allowed to cool and added purified water to create a volume of $50 \mathrm{ml}$ and then filtered using a filter paper. (Momodu and Anyakora 2010; Sehgal et al. 2012; Zhou et al. 2019; Huzefa Shaikh et al. 2020). The heavy metals $\mathrm{Zn}, \mathrm{Cr}, \mathrm{Cu}, \mathrm{Pb}, \mathrm{Co}, \mathrm{Fe}, \mathrm{Mn}$ and $\mathrm{Ni}$ were studied at the Geo-chemical laboratory of the School of Earth Atmospheric Science, Department of Applied Geology, Madras University, using the Atomic Absorption Spectrometer Varian and Perkin Elmer. The coordinates were taken at each position using a GPS model, GARMIN etrex 10 . The positions were taken into GIS applications and the attribute was created with spatial data in points. The $\mathrm{pH}, \mathrm{EC}, \mathrm{TDS}$ and selected heavy metal spatial distribution maps were developed using the inverse distance Weighted approach IDW using Arc GIS 10.2 (Suresh et al. 2010; Vetrimurugan et al. 2017; Redvan and Nasim 2017; Severini et al. 2018; Yang et al. 2020; Mahapatra et al. 2020). Geology map was digitized based on the District resource map (Geological Survey of India).

Each and every parameter was correlated with WHO 2017 and BIS 2012 standards to classify risk hazardous ranks. The spatial distribution thematic were maps prepared based on the ranks (Mahapatra et al. 2020). After creating the entire thematic layers using SMCE overlay analysis was made using all the thematic layers and finally, to identify the risk hazardous and high risk hazardous zones (Ravindra et al. 2019). Detailed methodology flowchart is given in Fig. 2.

Taxonomy diagram is constructed using total concentration of trace metals $\mathrm{Vs} \mathrm{pH}$ of the groundwater. All multivariate analysis was performed using Statistica version 7 for Windows. The correlation matrix, factor (Varimax Rotated) was used to reduce data and to analyze the relationship between the analyzed trace elements and the likely possible sources of these metals like $\mathrm{Zn}, \mathrm{Cr}, \mathrm{Cu}, \mathrm{Pb}, \mathrm{Co}, \mathrm{Fe}, \mathrm{Mn}$ and Ni (Prasad and Jaiprakas, 1999; Faraham et al., 2003; Varol 2019; Belkhiria et al. 2017). Detailed methodology flowchart is given in Fig. 2.

\section{Results and discussion}

The present research work narrates the Gadilam River basin groundwater quality and assesses the risk in terms of area with Archaean formation, Quaternary formation, Tertiary formation and Cretaceous formation. Experiments are carried out with data of November 2018. The Geological formation wise least, extreme and mean values of trace elements are shown in Table 1.

\section{Archaean formation}

The concentration of hydrogen ions $(\mathrm{pH})$ is varying from 7.12 to 8.12 , with an average of 7.51, although the whole formation is below the allowable limit. With an average of $1448.70 \mu \mathrm{mohs} / \mathrm{cm}$, electrical conductivity (EC) ranges from $454 \mu \mathrm{mohs} / \mathrm{cm}$ to $2600 \mu \mathrm{mohs} / \mathrm{cm}$. Dissolved inorganic salts are suggested for conductivity with an average of $1014.14 \mathrm{mg} / \mathrm{L}$, Gross Dissolved Solids (TDS) ranges from 318 to $1820 \mathrm{mg} / \mathrm{L}$. Due to condensed colloids in liquids, the EC and TDS values are considered higher in some samples. Complete dissolved solid describes all solids that are dissolved in water, typically mineral salts (Verma et al. 2012; Dahaan et al. 2016).

Zinc $(\mathrm{Zn})$ and copper $(\mathrm{Cu})$ concentrations are below acceptable limits. For the Archaean formation, chromium $(\mathrm{Cr})$ is maximum $1.72 \mathrm{mg} / \mathrm{L}$ and averages $0.66 \mathrm{mg} / \mathrm{L}$, lead $(\mathrm{Pb})$ is maximum $0.98 \mathrm{mg} / \mathrm{L}$ and averages $0.51 \mathrm{mg} / \mathrm{L}$, cobalt (Co) is maximum $2.39 \mathrm{mg} / \mathrm{L}$ and averages $1.21 \mathrm{mg} / \mathrm{L}$, iron $(\mathrm{Fe})$ is maximum $0.99 \mathrm{mg} / \mathrm{L}$ and averages $0.39 \mathrm{mg} / \mathrm{L}$, manganese $(\mathrm{Mn})$ is maximum $0.97 \mathrm{mg} / \mathrm{L}$ and averages.

\section{Cretaceous formation}

Just one groundwater sample was obtained from the Cretaceous formation of Limestone, calcareous shale and clay. This analytical result of the general concentrations of water quality parameters is acceptable under the WHO norm, except for the values of electrical conductivity (1517 $\mu \mathrm{mohs} / \mathrm{cm})$.

Heavy metal amounts are not permissible under the WHO standard, except for zinc $(0.22 \mathrm{mg} / \mathrm{L})$ and copper $(0.75 \mathrm{mg} / \mathrm{L})$ levels in $\mathrm{mg} / \mathrm{L}$.

\section{Tertiary formation}

In the tertiary formation, the percentage of hydrogen $(\mathrm{pH})$ varies from 7.21 to 8.21 with an average of 7.52, the electrical conductivity (EC) ranges from 288 mohs/ $\mathrm{cm}$ to $1887 \mathrm{mohs} / \mathrm{cm}$ with an average of $809.57 \mathrm{mohs} / \mathrm{cm}$, 


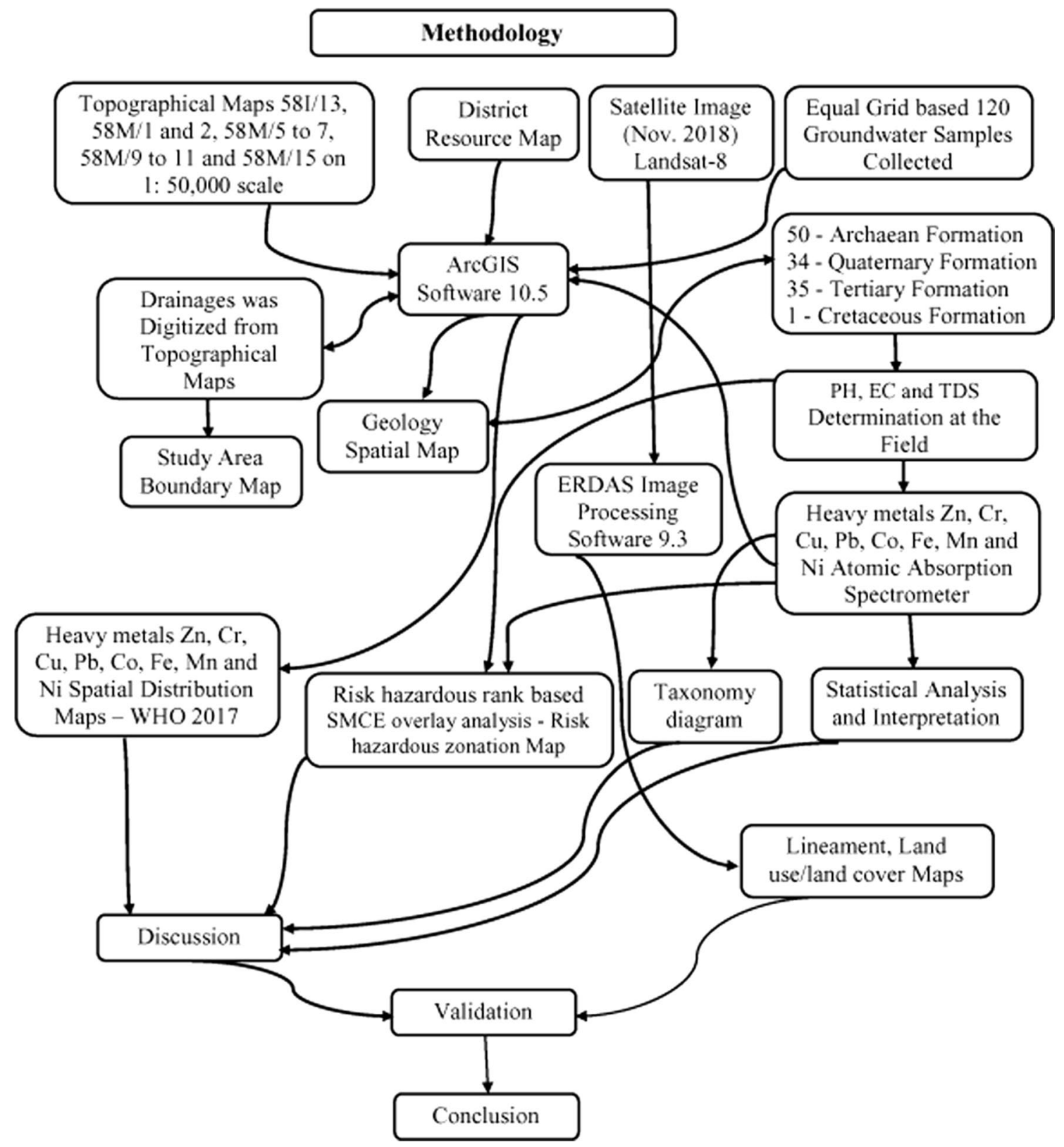

Fig. 2 Detailed methodology flowchart

and the overall dissolved solid (TDS) ranges from 202 to $1321 \mathrm{mg} / \mathrm{L}$ with an average of $566.77 \mathrm{mg}$.

Zinc ( $\mathrm{Zn}$ ) minimum and maximum values vary from 0.17 to $9.26 \mathrm{mg} / \mathrm{L}$, with an average of $1.30 \mathrm{mg} / \mathrm{L}$; chromium $(\mathrm{Cr})$ minimum and maximum values range from 0.11 to $1.74 \mathrm{mg} / \mathrm{L}$, with an average of $0.58 \mathrm{mg} / \mathrm{L}$. Copper $(\mathrm{Cu})$ minimum and maximum values range from 0.06 to $0.82 \mathrm{mg} / \mathrm{L}$ with an average of $0.34 \mathrm{mg} / \mathrm{L}$; lead $(\mathrm{Pb})$ least, extreme, and average values range from 0.26 to 0.99 and $0.55 \mathrm{mg} / \mathrm{L}$, respectively.

In Tertiary formation, Cobalt (Co) minimum and maximum values range from 0.15 to $0.93 \mathrm{mg} / \mathrm{L}$ and mean value of
$0.51 \mathrm{mg} / \mathrm{L}$, iron $(\mathrm{Fe})$ minimum and maximum values range from 0.15 to $0.93 \mathrm{mg} / \mathrm{L}$ and mean of $0.51 \mathrm{mg} / \mathrm{L}$, manganese (Mn) minimum and maximum values 0.17 to $1.03 \mathrm{mg} / \mathrm{L}$ and mean of $0.54 \mathrm{mg} / \mathrm{L}$, nickel $(\mathrm{Ni})$ minimum and maximum values 0.17 to $1.03 \mathrm{mg} / \mathrm{L}$ and mean of $0.54 \mathrm{mg} / \mathrm{L}$.

\section{Quaternary formation}

In Quaternary formation, general water quality parameters such as percentage of hydrogen $(\mathrm{pH})$ vary from 7.17 to 8.05 with an average of 7.44 , electrical conductivity (EC) ranges from $372 \mathrm{mohs} / \mathrm{cm}$ to $3400 \mathrm{mohs} / \mathrm{cm}$ with an average of 


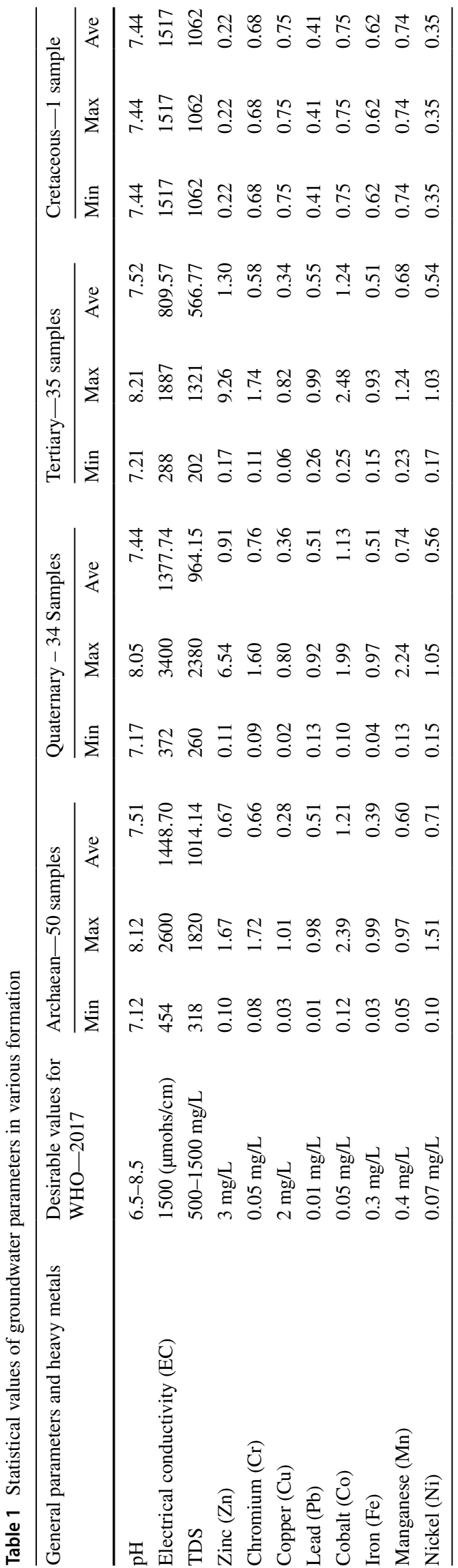

$1377.74 \mathrm{mohs} / \mathrm{cm}$, and Total Dissolved Solids (TDS) vary from 260 to $2380 \mathrm{mg} / \mathrm{L}$ with an average of 904 .

In Quaternary formation, the concentration of heavy metals zinc $(\mathrm{Zn})$ is $0.11-6.54 \mathrm{mg} / \mathrm{L}$ and the mean is $0.91 \mathrm{mg} / \mathrm{L}$, chromium $(\mathrm{Cr})$ is a minimum and a maximum of $0.09-1.60 \mathrm{mg} / \mathrm{L}$ and a mean of $0.76 \mathrm{mg} / \mathrm{L}$, copper $(\mathrm{Cu})$ is a minimum and a maximum of $0.02-0.80 \mathrm{mg} / \mathrm{L}$ and a mean of $0.36 \mathrm{mg} / \mathrm{L}$, Lead $(\mathrm{Pb})$ is a minimum and a maximum of 0.13 to $0.92 \mathrm{mg} / \mathrm{L}$ with an average of $0.51 \mathrm{mg} / \mathrm{L}$. Cobalt (Co) ranges from 0.10 to $1.99 \mathrm{mg} / \mathrm{L}$ with an average of $1.13 \mathrm{mg} / \mathrm{L}$, Iron $(\mathrm{Fe})$ is a minimum and a maximum of $0.04-0.97 \mathrm{mg} / \mathrm{L}$ with an average of $0.51 \mathrm{mg} / \mathrm{L}$, manganese $(\mathrm{Mn})$ is a minimum and a maximum of $0.13-2.24 \mathrm{mg} / \mathrm{L}$ and a mean of $0.74 \mathrm{mg} / \mathrm{L}$ and nickel $(\mathrm{Ni})$ is a minimum and a maximum of $0.15-1.05 \mathrm{mg} / \mathrm{L}$ and a mean of $0.56 \mathrm{mg} / \mathrm{L}$.

\section{Formationwise concentrations of heavy metals}

The heavy metal concentrations in groundwater for various geological formations are observed. Zinc concentration is gradually decreasing from Tertiary $>$ Quaternary $>$ Archaean $>$ Cretaceous formation. High concentration of zinc is recorded in tertiary formation and average concentration is also higher than other formations.

Chromium, lead and cobalt concentrations are showing decreasing trend from Tertiary $>$ Archaean $>$ Quaternary $>$ Cretaceous formation. High chromium, lead and cobalt concentrations are recorded in tertiary formation and lead and cobalt highest average values are noticed in same formation.

Manganese concentrations are observed as decreasing from Quaternary $>$ Tertiary $>$ Archaean $>$ Cretaceous formation. High manganese concentration is recorded in quaternary formation as well as highest average values in same formation.

Iron and Nickel concentrations are varying as Archaean $>$ Quaternary $>$ Tertiary $>$ Cretaceous formation. High iron concentration is recorded in Archaean formation but, highest average values noticed in cretaceous formation. High concentration and average value of Nickel is observed in Archaean formation.

Copper concentration in various formations can be arranged as Archaean $>$ Tertiary $>$ Quaternary $>$ Cretaceous formation. High copper concentration is recorded in Archaean formation but, highest average values noticed in cretaceous formation.

\section{Spatial Interpolation}

\section{Hydrogen potential}

Water quality map for $\mathrm{pH}$ was prepared for the study area shown in Fig. 3. From the spatial variation with contour 


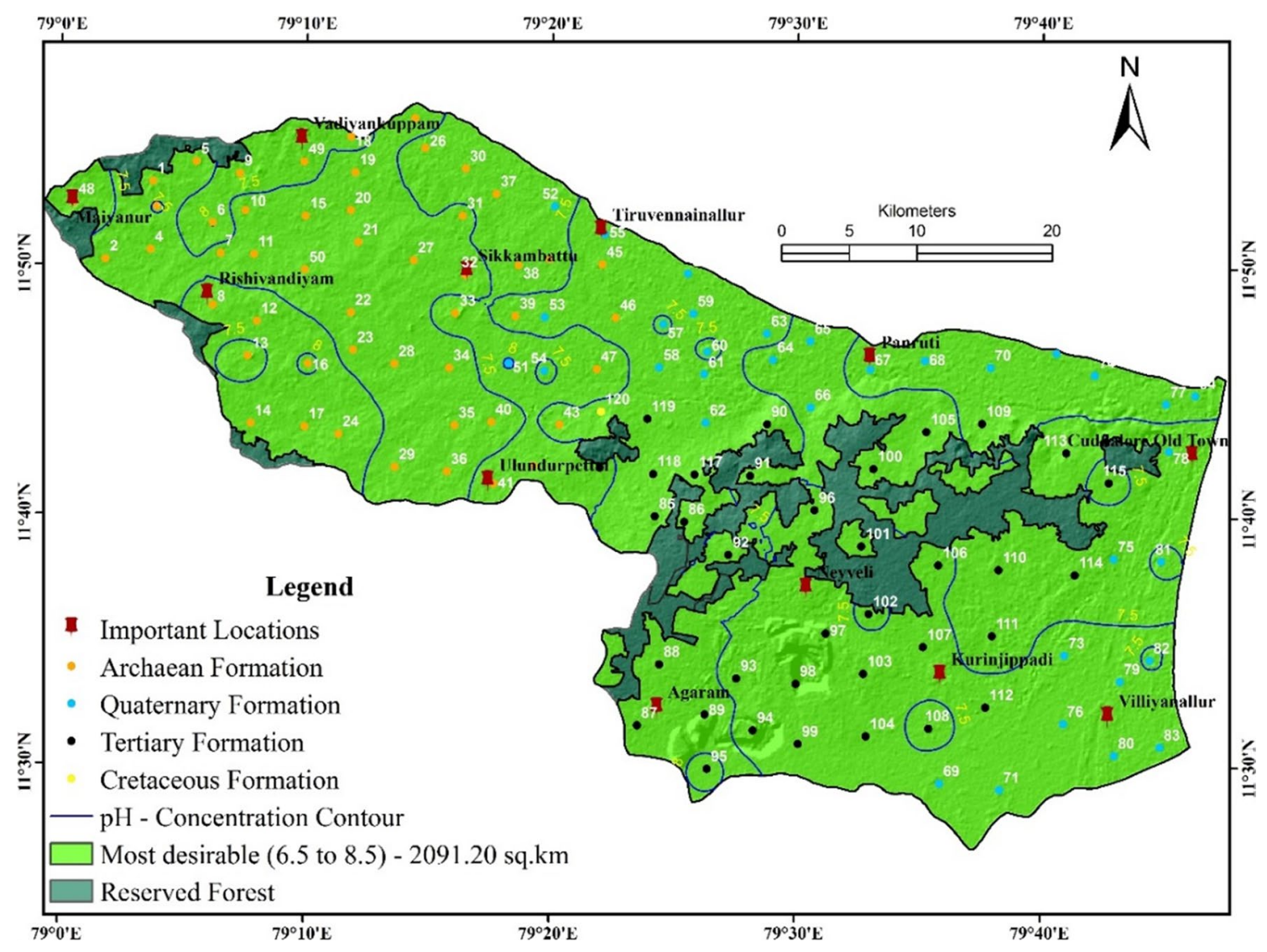

Fig. 3 Groundwater quality map- $-\mathrm{pH}$

lines of $\mathrm{pH}$ map are seen for all formations, none of the sample of the Gadilam River basin exceeding limit for drinking purposes.

\section{Electrical conductivity}

Water quality map for EC was prepared for the study area shown in Fig. 4. The map displays the spatial variation with contour lines of EC, exhibiting exceeding limit for drinking purposes for Twenty-one samples in Archaean formation. Some of the sample places are lying in between two rock types; many of the sample places are located in hornblende biotite gneiss. Therefore, it is weaker plain which may have significant influence of rock water interaction (Verma et al. 2012).

In Quaternary formation, two samples are in not permissible limit. These sample places are lying in between (contact zone) flood basin deposit with hornblendebiotite gneiss. Therefore, the weaker plane might have played a significant influence on rock water interaction. Another group of samples places were located in Sea shore line. Higher value of EC can be attributed to sea water intrusion.
From overall EC values observation, that majority of the Ec values under permissible class are observed in tertiary formation. The entire tertiary formation is having samples under permissible limit except two samples Mel Vadak-

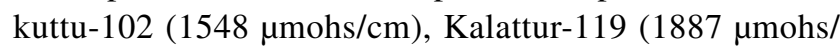
$\mathrm{cm})$. These samples are located along the (contact zone) sand stone, clay, lignite deposit and flood basin deposit contacts and nearby lignite mining area. Therefore, the primary porosity and bedding plane may have significant influence of rock water interaction and anthropogenic activities.

The higher concentration is observed along the middle of the basin and east coast of the Gadilam River basin. The rest of the portion is having less than $1500 \mu \mathrm{mohs} / \mathrm{cm}$. Generally, the basin is in permissible EC limit except some location along the coast and in central portion of the basin. This result indicates that the leaching of secondary salts and anthropogenic activities in upstream side and may be sea water intrusion in the downstream side.

\section{Total dissolved solids}

Water quality map for TDS was prepared for the study area shown in Fig. 5. From the spatial variation TDS contour 


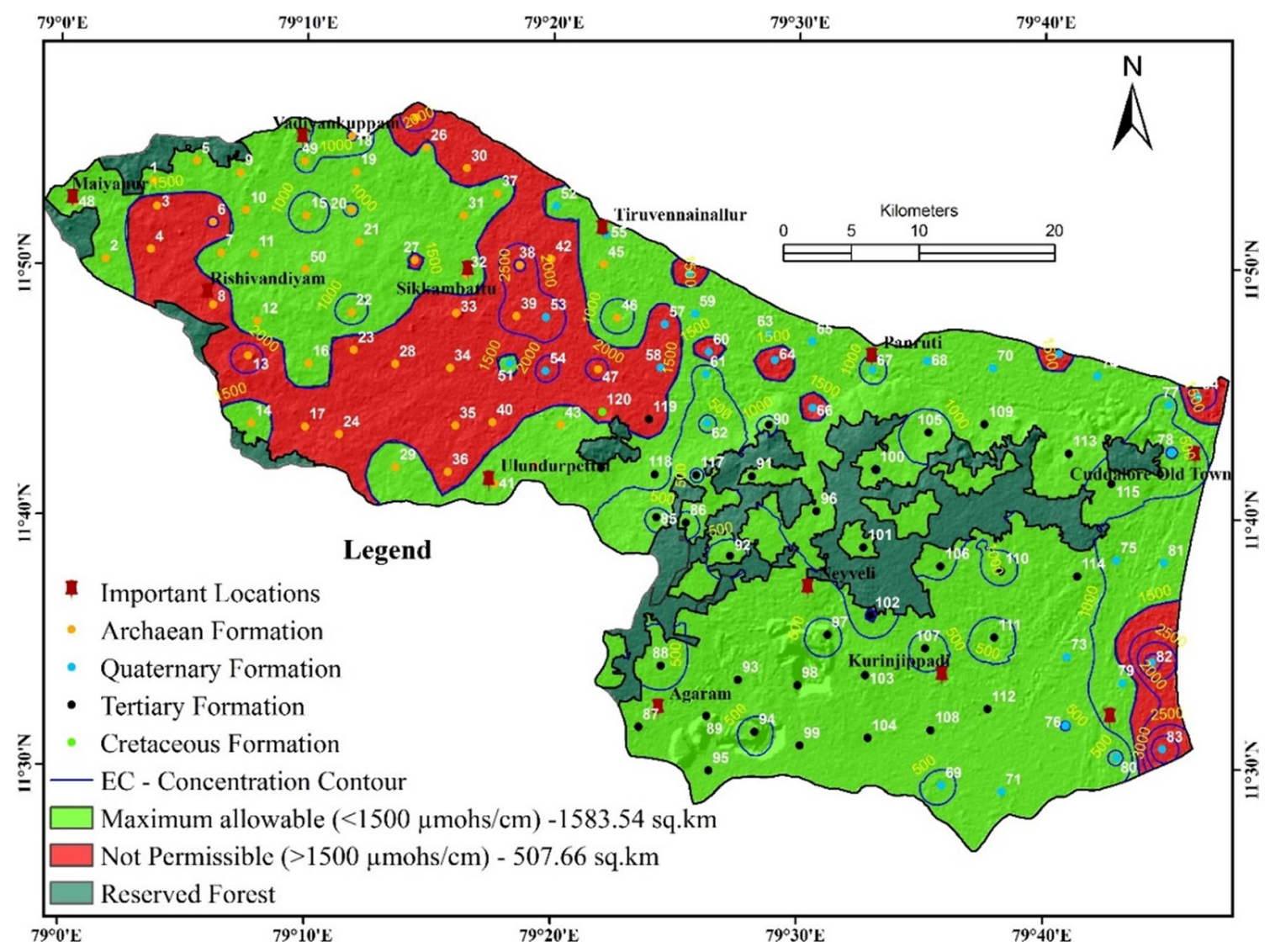

Fig. 4 Groundwater quality map-EC

lines map, it is seen the exceeding limit values of TDS for drinking purposes for four samples in Archaean formation. The maximum concentration of TDS was found at Sikkadu-13 (1657 mg/L). This sample places were located in hornblende-biotite gneiss with agricultural land and nearby water body. The reason of high concentration, it may be attributed to highly weathered nature of the rock.. Three samples, Kulappakkam-25 (1687 mg/L), Amur-38 (1820 mg/L), Attur-39 (1554 mg/L), these sample places are in between (contact zone) hornblende-biotite gneiss with flood basin. Therefore, it is weaker plane and pores may have significant influence on rock water interaction (Al Dahaan et al. 2016; Mahmoud et al. 2016).

In Quaternary formation, only four samples are exceeding permissible limit. The higher values of TDS are found at Kilkuppam-53 (1617 mg/L). This sample places are located in between (contact zone) flood plain deposit with hornblende-biotite gneiss. Therefore, the weaker plane may have significant influence of rock water interaction. The samples from Vandiyampalayam-82 (2240 mg/L), Karikkuppam-83 (2380 mg/L), Cuddalore New Town-84 (1645 mg/L) are lying along Sea shore line so, the higher values can be attribute to sea water intrusion.

The Tertiary formation groundwater samples are within limiting value in rainy season. The higher concentration is observed along the north and north western portion of catchment area and east coast of the Gadilam River basin. The rest of the part is having less than $1500 \mathrm{mg} / \mathrm{L}$. Generally, the basin is in permissible TDS limit except few locations along the coast and in some pockets of north and north western part of the basin in both seasons. This result indicates that the leaching of secondary salts in upstream side and anthropogenic activities and sea water intrusion in the downstream side may be attributed for higher concentration.

\section{Zinc (Zn)}

Zinc is needed for plants and animals and it is responsible for undesirable astringent taste to water. The zinc spatial distribution map (Fig. 6) for November 2018 at the time of flooding was prepared by setting the not permissible 


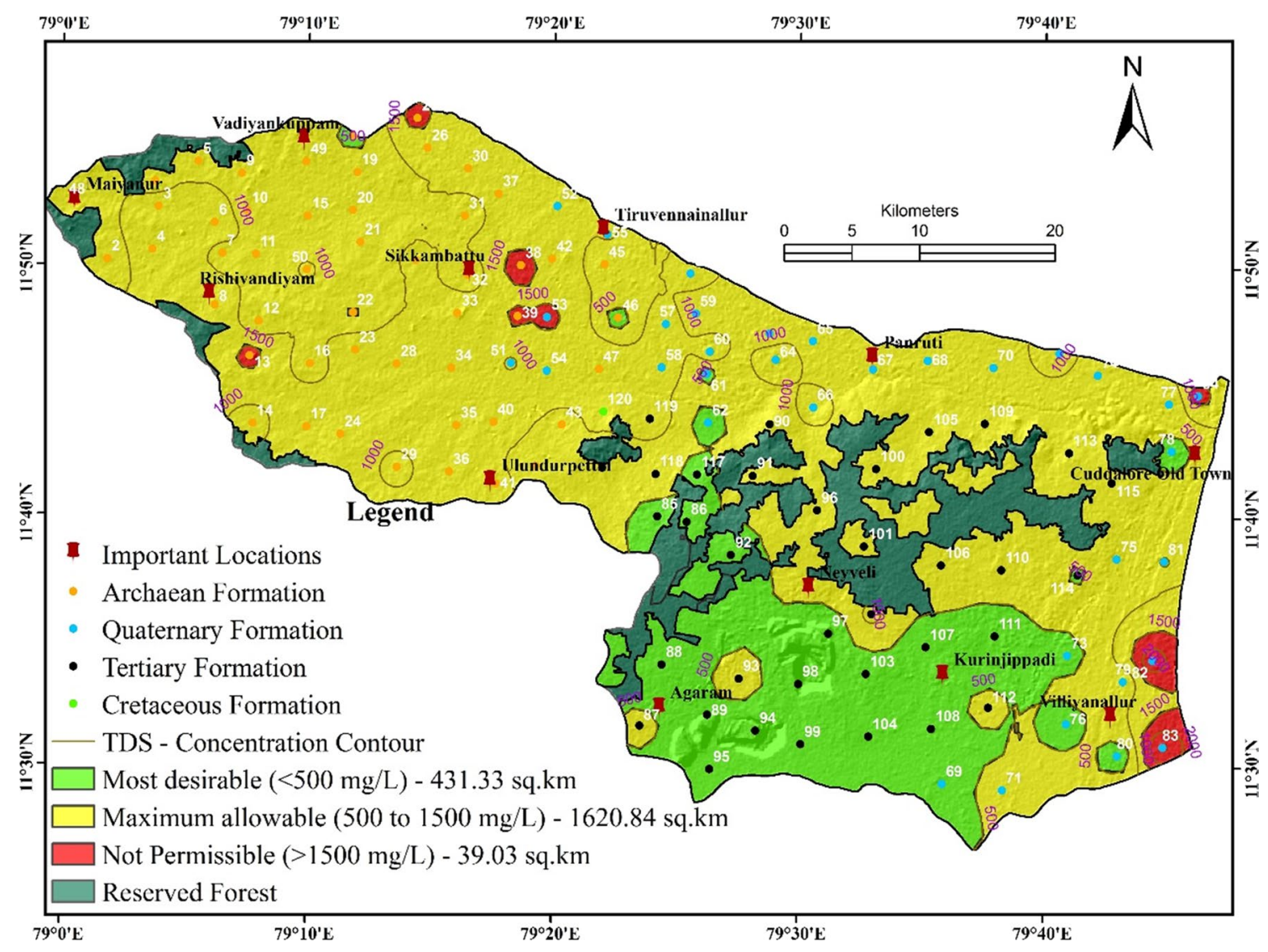

Fig. 5 Groundwater quality map-TDS rainy (November 2018)

limit ( $>3 \mathrm{mg} / \mathrm{L}$ ) as the water with zinc less than $3 \mathrm{mg} / \mathrm{L}$ is considered good for drinking purposes. Only $4 \%$ of samples come under not permissible for drinking purposes (WHO 2017). The map shows that $96.22 \%$ of the study area falls within permissible limit of zinc. Extreme level of Zinc is documented at Kuravaampalayam-106 $(9.26 \mathrm{mg} / \mathrm{l})$ followed by Ayatturai-108 and Maampatti-94 $(6.54 \mathrm{mg} / \mathrm{l})>$ Therku Melur-84 (6.25 mg/l) > Marudur-98 $(4.15 \mathrm{mg} / \mathrm{l})$.

Sample nos. like 84, 94 and 106 locations are observed in Sandstones, Clay, Lignite of Tertiary formation and 98 and 108 locations are observed in Flood basin/back swamp deposits of Quaternary formation, are displaying high values of zinc. The multi-sulfide $(\mathrm{Pb}-\mathrm{Zn}-\mathrm{Cu})$ deposits near catchment Kanankadu R.F. (Part Mamandur multi-sulfide deposits) do not seem to have influence as the zinc concentration is high only in tertiary formation (Gope et al. 2017). Inputs from agricultural activities, for instance, fertilizers, herbicides and pesticides and human activities may be attributed for higher concentrations (Shen et al. 2017).

\section{Chromium (Cr)}

Study finds $100 \%$ samples are not fall under permissible limit with respect to the level set by WHO 2017. Spatial distribution map (Fig. 7) shows that maximum (More than $1 \mathrm{mg} / \mathrm{L}$ ) value of chromium is found at stations Gudalur, Vinnamangalam, Elavansuur, Puliampatti, Kanaiyar, Kunnathur, Sikkambattu, Pudur and Kommasamudram in Archaean formation. Small quantity of chromium occurs in ultramafic and basic rocks and soils but high values of chromium in groundwater are due to industrial sewages, agronomic and sewage runoff (Dixit and Tiwari 2008).

The maximum value of chromium is found at Virapperumanallur, Toppiyankulam and Cuddalore stations in Quaternary formation. It may be attributed to leaching of solid wastes and agricultural run of let off into the groundwater and sewage run off (Mohiuddin et al. 2015).

The maximum (More than $1 \mathrm{mg} / \mathrm{L}$ ) value of chromium is found at stations Mudhanai and Parvathipuram in Tertiary formation. The higher value of chromium content is a hexavalent form of chromium that causes a wide range 


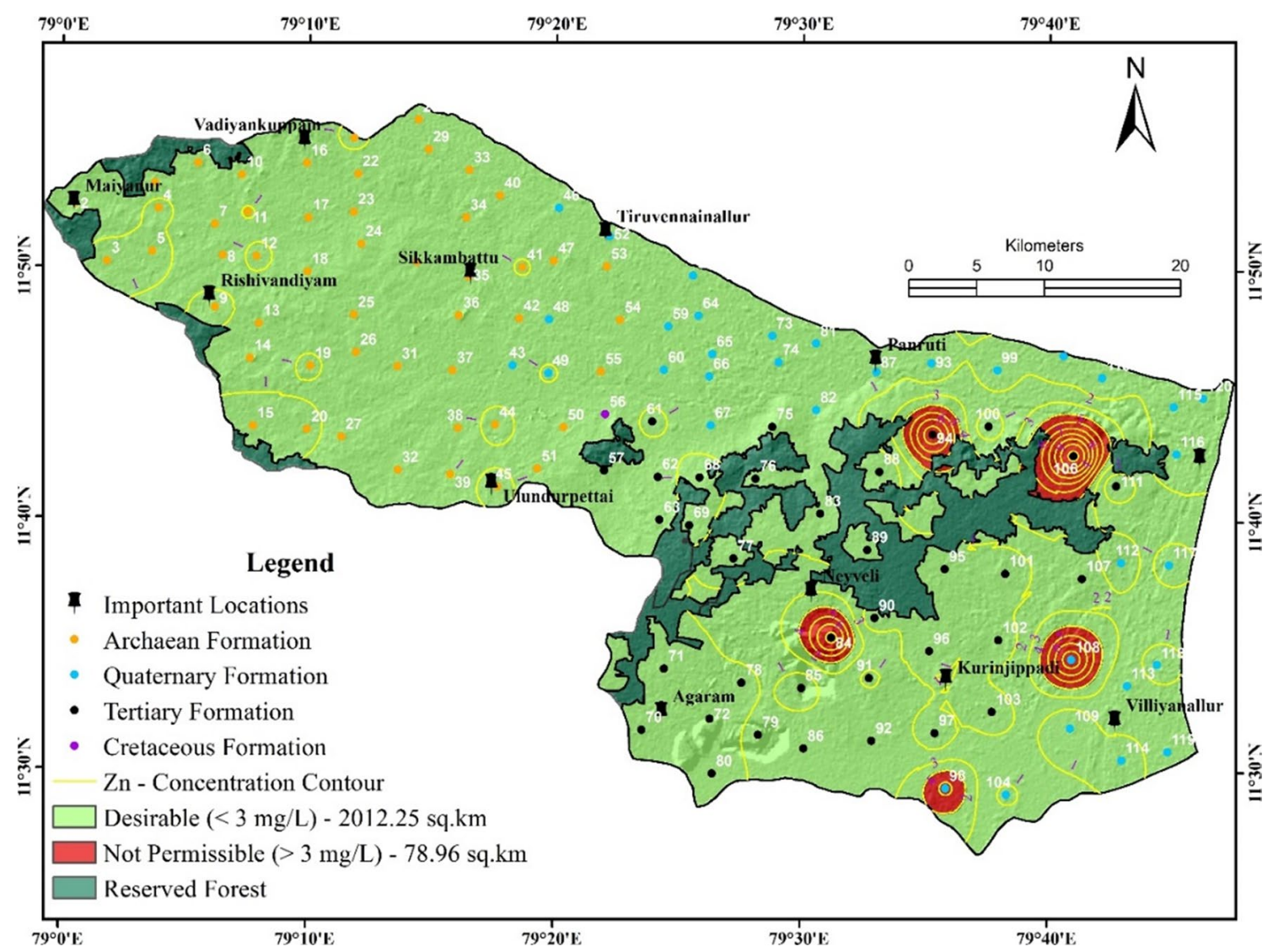

Fig. 6 Spatial variation with contour map of zinc in groundwater

of human health effects including mutagenic and carcinogenic risks (Mahapatra et al. 2020).

\section{Copper (Cu)}

Copper is an unpleasant metallic, bitter taste to drinking water. Last two eras, copper production is very high so, leading to the increased concentration of copper in the environment. Study predicts $100 \%$ samples are permissible limit with respect to WHO 2017 standards. The copper concentration (Fig. 8) of the groundwater is ranging from 0.02 to 1.01 . Source of the copper contamination may be due to influx of industrial and domestic wastes (Zahir Hussain et al. 2013; Kannan and Mani 2015). Minerals dissolution also leads to enhance the high values of copper.

\section{Lead $(\mathrm{Pb})$}

Figure 9 shows the lead distribution in the study area. Study finds $100 \%$ samples are not permissible with respect to the standards of WHO. It may be attributed to leaching of solid wastes and agricultural run of and let off into the groundwater and sewage run off (Dahl et al. 2014).

The maximum (More than $0.01 \mathrm{mg} / \mathrm{L}$ ) value of lead is found at stations Tayilgunampattanam-102 (0.99 mg/L), Konakkalavadi-7 and Sangrur $(0.01 \mathrm{mg} / \mathrm{l})$ as shown in Fig. 6. The lead concentration in the groundwater is due to the chemical weathering of lead and zinc elements occurred in metamorphic and sedimentary rocks may have significant influence on lead in groundwater.

\section{Cobalt (Co)}

Groundwater containing cobalt metal can have an erythropoietic effect such as increased incidence of goiter among most mammals, including humans (Purushotham et al. 2013). The maps (Fig. 10) show that $100 \%$ of the study area is $>0.05 \mathrm{mg} / \mathrm{L}$. The extreme level of Cobalt is found at Valichcherippaalaiyam-111 $(2.48 \mathrm{mg} / \mathrm{L})$ while lowest concentration is recorded at Deviyanandal-66 $(0.10 \mathrm{mg} / \mathrm{L})$ as shown in Fig. 10. The Cobalt concentration in the 


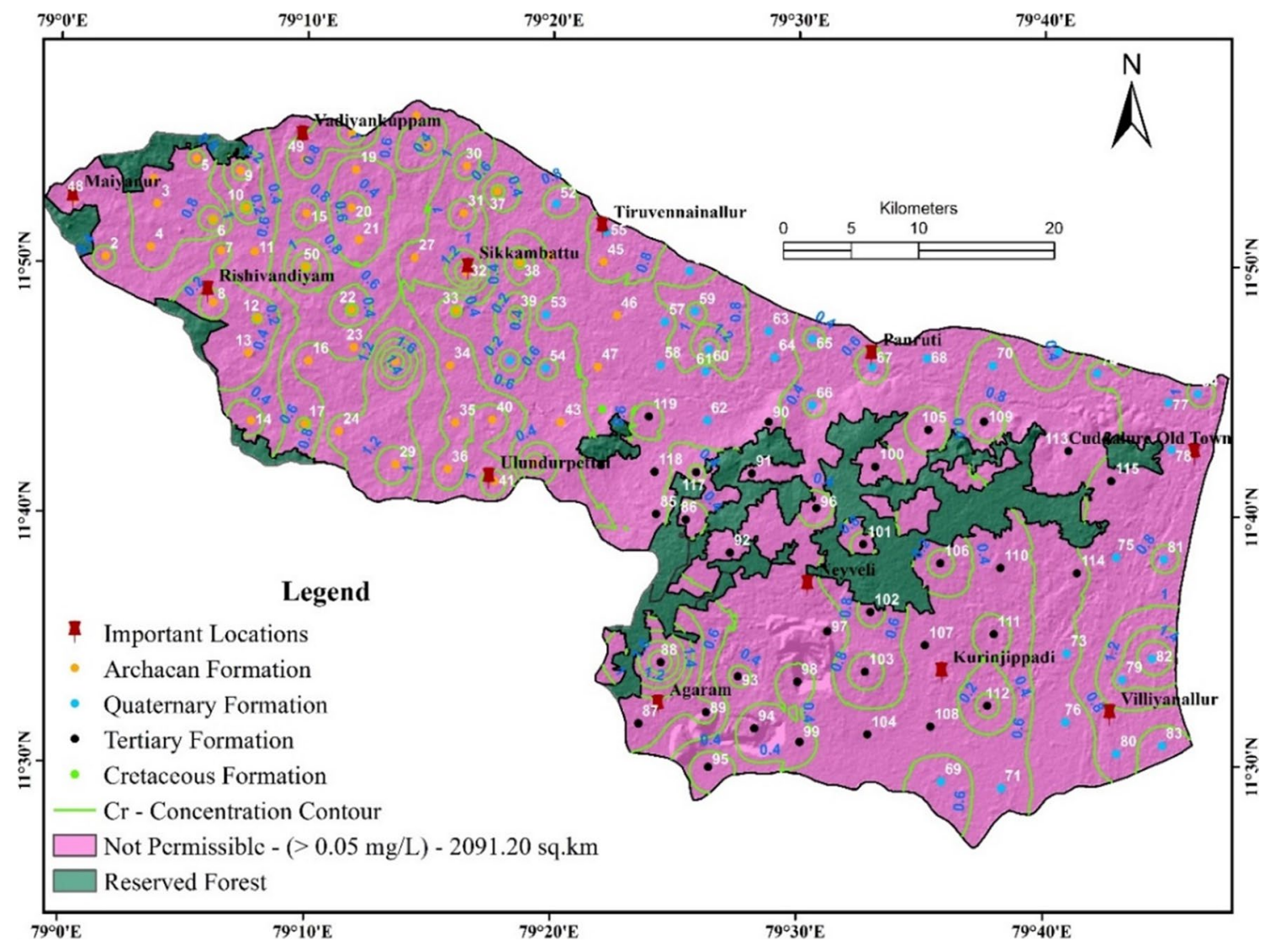

Fig. 7 Spatial variation with contour map of chromium in groundwater

groundwater is due to the leaching from solid waste sites, and small amount found in country rocks, soil, plants and animals manure may have significant influence of cobalt in groundwater (Philip Njoku Obasi and Bennard Benedict Akudinobi 2020). The cobalt is notable toxic element, it is extreme level of Cobalt can cause death (Robert L. Bridges et al. 2020).

\section{Iron (Fe)}

Higher values with respect to permissible level are recorded in 17 samples out of 50 samples, i.e., 34\% stations in Archaean formation. Quaternary formation groundwater $\mathrm{Fe}$ concentrations are shows that the ten stations come under permissible class out of 34 samples. Seven samples out of 35 samples in Tertiary formation are come under permissible class (Fig. 11).

Iron concentration in groundwater is ranging from 0.03 to 0.99 and means value of $0.46 \mathrm{mg} / \mathrm{L}$ (Fig. 11). The WHO standard drinking water limit is $<0.3 \mathrm{mg} / \mathrm{L}$. Higher values is observed in $28 \%$ of samples. The maximum concentration of iron is found at Paaduur-50 $(0.99 \mathrm{mg} / \mathrm{L})$ while lowest concentration is recorded at Amuur- $41(0.03 \mathrm{mg} / \mathrm{L})$ as shown in Fig. 11.

Mostly, the iron concentration in the unconfined aquifer (hard rocks) is higher than the Sedimentary formation (Confined Aquifer). The presence of iron in the hard rock terrain increases the iron concentration in the groundwater (Papachristodoulou et al. 2015).

\section{Manganese (Mn)}

The values of manganese are more than the permissible limit of $0.4 \mathrm{mg} / \mathrm{L}$ (WHO 2017) for $80 \%$ of the groundwater samples. Increase in manganese may be due to the influence of domestic wastes, natural geological rocks and intrusion of industrial effluents (Mohamed Sihabudeen et al. 2015).

The spatial distribution map (Fig. 12) shows that $6.86 \%$ is less than $0.4 \mathrm{mg} / \mathrm{l}$ of the study area for Manganese. From the Manganese spatial map it is observed that majority 


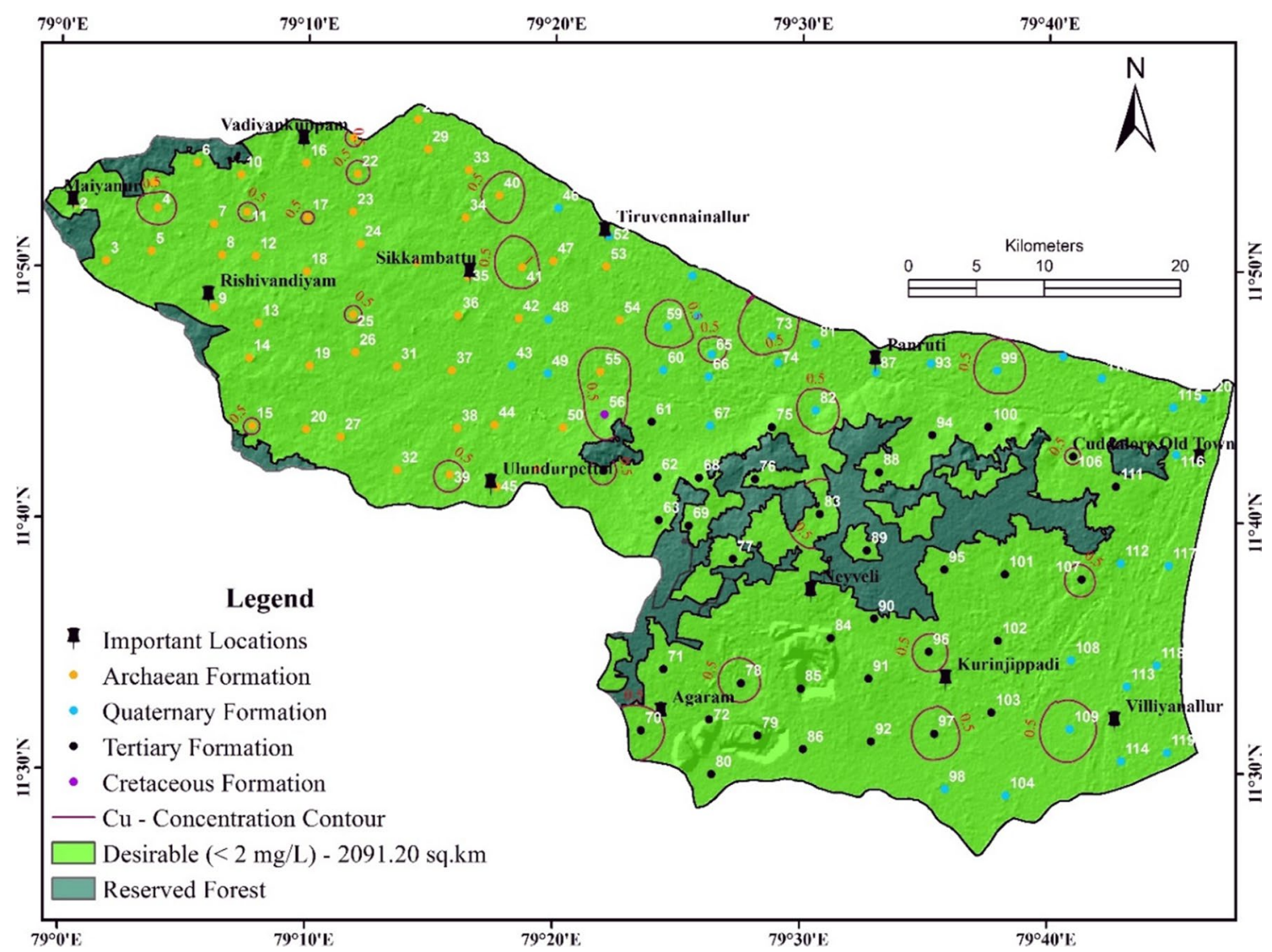

Fig. 8 Spatial variation with contour map of copper in groundwater

(93.40\%) of portions fall above permissible limit for drinking purposes, with respect to WHO standard.

Increase in manganese may be due to the influence of domestic wastes, natural rocks and intrusion of industrial effluents (Paul et al. 2019a).

\section{Nickel (Ni)}

Nickel concentration varies from 0.10 to $1.51 \mathrm{mg} / \mathrm{L}$. Present study reveals that $100 \%$ of the area falls under above permissible limit for drinking purpose. The nickel spatial distribution map (Fig. 13) is prepared by setting the desirable limit $(<0.07 \mathrm{mg} / \mathrm{L})$. The groundwater with nickel less than $0.07 \mathrm{mg} / \mathrm{L}$ is considered good for drinking purposes (WHO 2017). The ultramafic rocks are the main source for the Nickel (El Amari et al. 2014; Engwa et al. 2018).

\section{Geometry of correlation matrix}

The correlation coefficient application has been applied to study the relationship between two or more hydrological variables and also to investigate the dependence between successive values of series of hydrological data. The groundwater quality of trace metals is considered for correlation. In Archaean formation Groundwater samples, good correlation exists between $\mathrm{Cu}-\mathrm{Zn}, \mathrm{Pb}-\mathrm{Cr}, \mathrm{Pb}-\mathrm{Cu}, \mathrm{Co}-\mathrm{Zn}, \mathrm{Co}-\mathrm{Pb}$, $\mathrm{Fe}-\mathrm{Zn}, \mathrm{Mn}-\mathrm{Fe}, \mathrm{Ni}-\mathrm{Zn}, \mathrm{Ni}-\mathrm{Co}, \mathrm{Ni}-\mathrm{Fe}, \mathrm{Ni}-\mathrm{Mn}$ (Table 2). $\mathrm{Mn}$ had significant positive correlation with $\mathrm{Fe}$ indicating percolation of secondary salts. Ni also showed significant correlation with $\mathrm{Fe}, \mathrm{Co}$ and $\mathrm{Zn}$ indicates leaching by chemical weathering (Srinivasamoorthy et al. 2009; Sappa et al. 2014). $\mathrm{Ni}$ and $\mathrm{Pb}$ poorly correlated with other ions that might be because of external sources of anthropogenic origin.

In quaternary formation groundwater samples, good correlation exists between $\mathrm{Cr}-\mathrm{Zn}, \mathrm{Cu}-\mathrm{Zn}, \mathrm{Co}-\mathrm{Zn}, \mathrm{Co}-\mathrm{Cu}$, $\mathrm{Co}-\mathrm{Pb}, \mathrm{Fe}-\mathrm{Pb}, \mathrm{Mn}-\mathrm{Fe}, \mathrm{Ni}-\mathrm{Cr}, \mathrm{Ni}-\mathrm{Fe}, \mathrm{Ni}-\mathrm{Mn}$ (Table 3) indicating weathering of minerals and rock. Co indicates existence of respectable relationship with $\mathrm{Cu}$ and $\mathrm{Pb}$, due to dissolution of the secondary salts. Substantial relationship of $\mathrm{Ni}$ with $\mathrm{Cr}$ and $\mathrm{Fe}$ exists due to minerals weathering (Paul et al. 2019a). Co and $\mathrm{Cr}$ are poorly correlated with other 


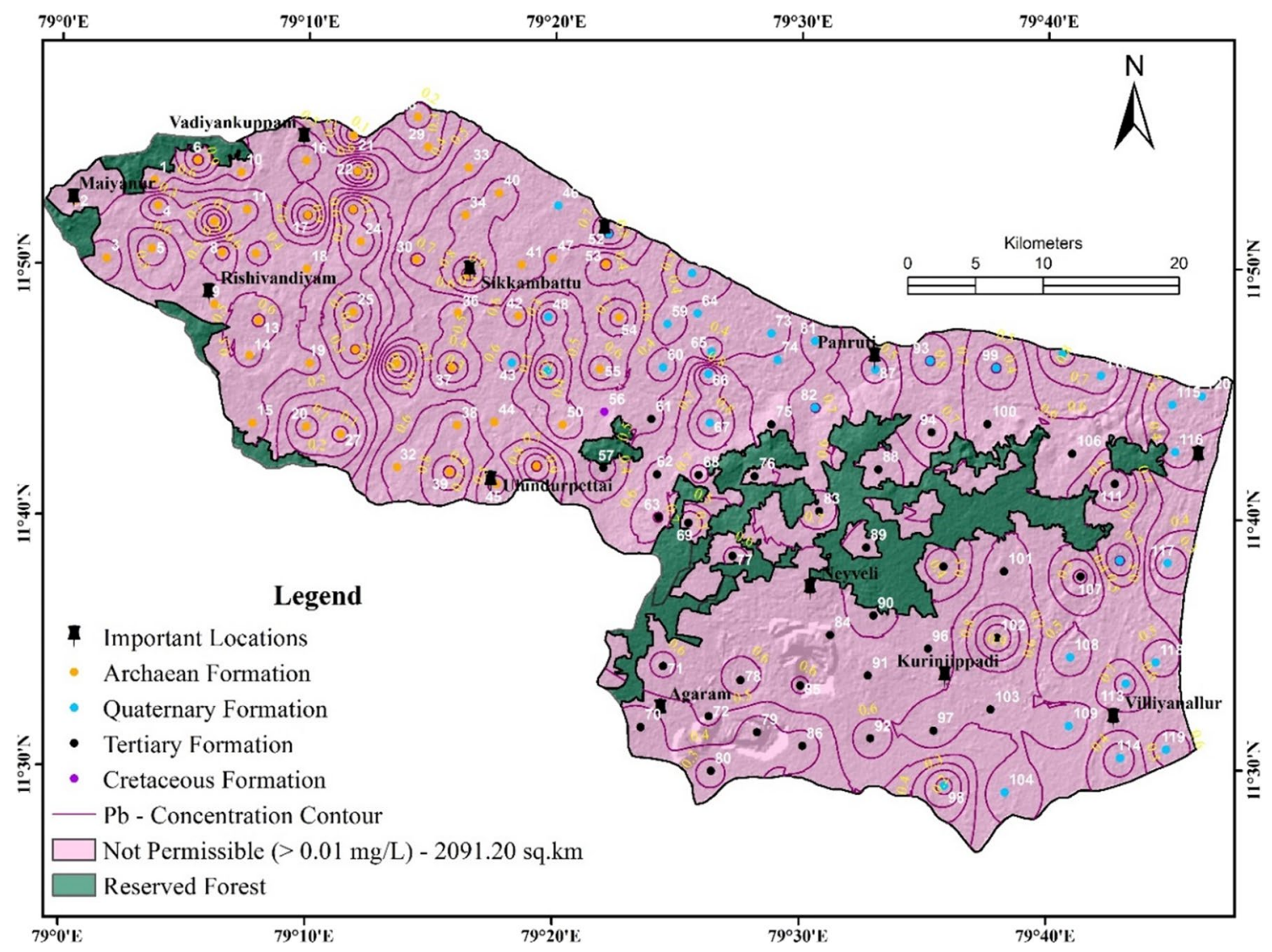

Fig. 9 Spatial variation with contour map of lead in groundwater

ions, might be because of external source of anthropogenic origin.

In tertiary formation groundwater samples, good correlation exists between $\mathrm{Co}-\mathrm{Zn}, \mathrm{Co}-\mathrm{Cr}, \mathrm{Co}-\mathrm{Pb}, \mathrm{Fe}-\mathrm{Zn}$, $\mathrm{Mn}-\mathrm{Cr}, \mathrm{Mn}-\mathrm{Pb}, \mathrm{Mn}-\mathrm{Co}, \mathrm{Ni}-\mathrm{Cr}, \mathrm{Ni}-\mathrm{Pb}, \mathrm{Ni}-\mathrm{Co}$ (Table 4) indicating weathering of minerals and rock. $\mathrm{Fe}$ and $\mathrm{Cr}$ is poorly correlated with other ions, might be because of fertilizers.

\section{Geometry of factor analysis}

Factor statistical application has been employed to study the relationship between two or more hydrological variables and also to investigate the dependence Eigen values above 1 and cumulative variance of $72.06 \%$ (Table 5) in Archaean formation.

The maximum variance of $22.59 \%$ for Factor 1 indicates the influence of high $\mathrm{Pb}, \mathrm{Cr}$ and $\mathrm{Cu}$ with moderate loading is indicate that metals from wastewater of various industries (Vetrimurugan et al. 2013). Factor 2 shows the influence of
$\mathrm{Zn}$ and Co may be due to the ultrabasic rocks and anthropogenic activities might have significantly influenced the presence of cobalt in groundwater. Factor 3 shows the influence of $\mathrm{Cu}$ may be due to the weathering of polymetallic sulfide deposits at the catchment and hence-geogenic and may be due to usage of micronutrient fertilizers. Most of these metals from wastewater of various industries contain some concentration (Kumar et al. 2012; Shan et al. 2013). Factor 4 shows the influence of $\mathrm{Pb}, \mathrm{Mn}, \mathrm{Cu}$ and $\mathrm{Fe}$ may be due to the weathering of Archaean rocks and polymetallic sulfides.

Factor analysis has extracted four important factors clarifying $70.19 \%$ total variance of the Quaternary formation heavy metal dataset. Factor 1 indicates the influence of high $\mathrm{Cr}$ and $\mathrm{Mn}$ water with the dominance of $\mathrm{Ni}$ and $\mathrm{Fe}$ indicating leaching of secondary salts, which are also present in seawater (Table 6). Factor 2 shows that impact of $\mathrm{Cu}, \mathrm{Zn}$ and $\mathrm{Co}$ the country rocks may have major impact of cobalt in groundwater (Brindha and Elango 2013). Fertilizers are a well-known source for copper, Factor 3 shows the influence 


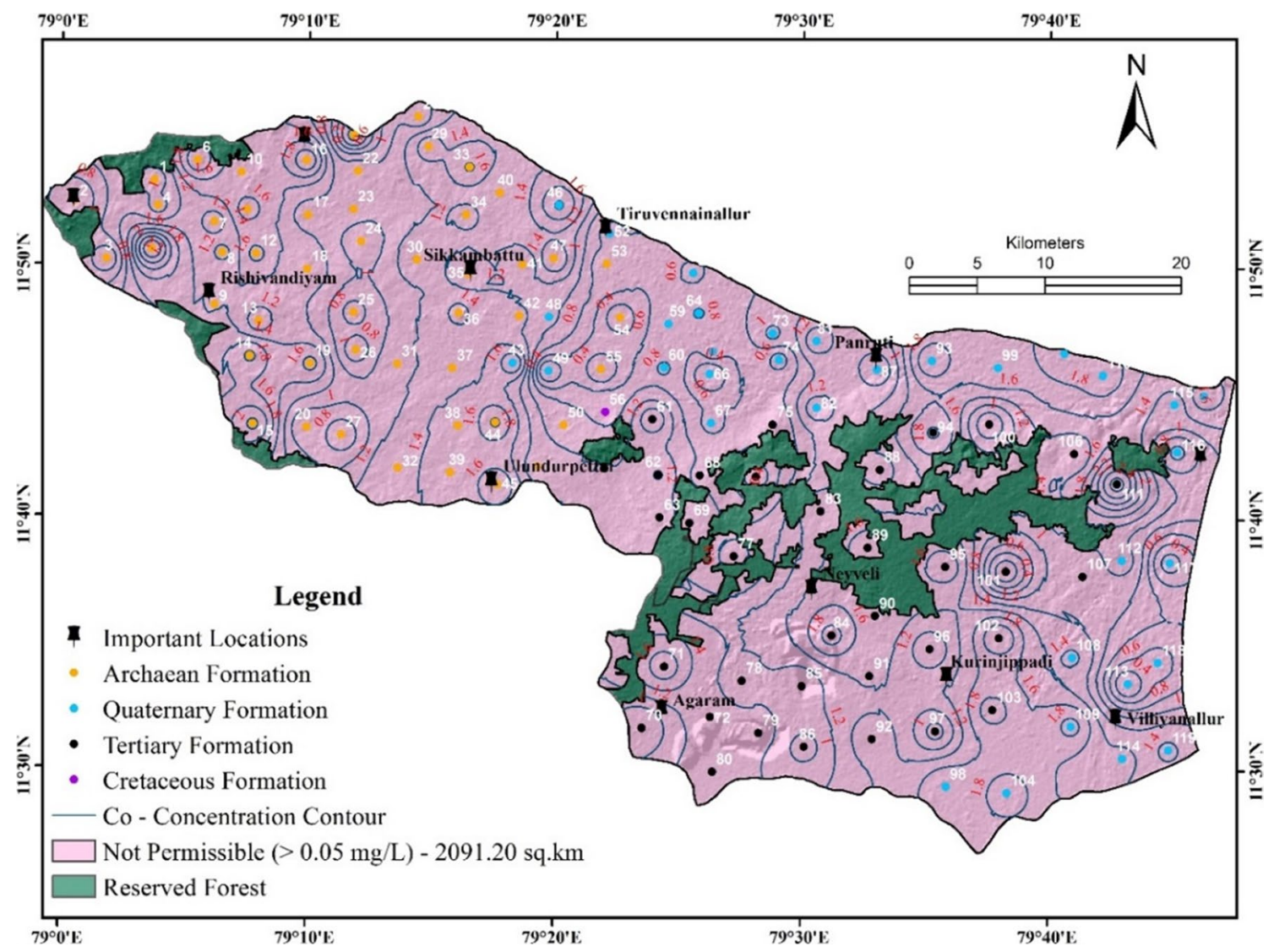

Fig. 10 Spatial variation with contour map of cobalt in groundwater

of $\mathrm{Cr}$ and $\mathrm{Fe}$ may be due to the Iron enrichment of country rock. Factor 4 shows the influence of $\mathrm{Ni}, \mathrm{Co}, \mathrm{Fe}$ and $\mathrm{Zn}$ occurring high concentration of Quaternary formation. It is clearly indicating an external pollution source (Wu et al. 2016).

Factor analysis rendered three significant factors explaining $70.19 \%$ of the total variance of the Tertiary formation heavy meal dataset (Table 7). Factor 1 indicates the influence of high $\mathrm{Cr}$ and $\mathrm{Mn}$ may be due to the mining and associated activates may contribute to $\mathrm{Cr}$ and $\mathrm{Mn}$ in groundwater. Factor 2 shows the influence of $\mathrm{Co}, \mathrm{Pb}$ and $\mathrm{Zn}$ which may be due to the country rocks and anthropogenic activities might have significant influence on cobalt in groundwater. Factor 3 shows the influence of $\mathrm{Ni}, \mathrm{Cr}, \mathrm{Cu}$ may be from outside sources. These metals from wastewater of various industries contain some concentration (Kumar et al., (2012). Factor 3 indicates that metals from wastewater of various industries.

Only one groundwater sample collected from Cretaceous formation of Limestone with calcareous shale and clay. This analytical result of the heavy metal concentrations is not permissible limit respect to WHO standard, except Zinc $(0.22 \mathrm{mg} / \mathrm{L})$ and Copper $(0.75 \mathrm{mg} / \mathrm{L})$ values in $\mathrm{mg} / \mathrm{L}$.

Overview of the heavy metal concentrations in groundwater for various geological formations is observed. Zinc concentration is gradually decreasing from Tertiary $>$ Quaternary $>$ Archaean $>$ Cretaceous formation. High concentration of zinc is recorded in tertiary formation and average concentration is also higher than other formations.

Chromium, lead and Cobalt concentrations are showing decreasing trend as Tertiary $>$ Archaean $>$ Quaternary $>$ Cretaceous formation. High chromium, lead and cobalt concentrations are recorded in tertiary formation and lead and cobalt highest average values are noticed in same formation.

Manganese concentrations are observed as Quaternary $>$ Tertiary $>$ Archaean $>$ Cretaceous formation. High manganese concentration is recorded in quaternary formation as well as highest average values in same formation. 


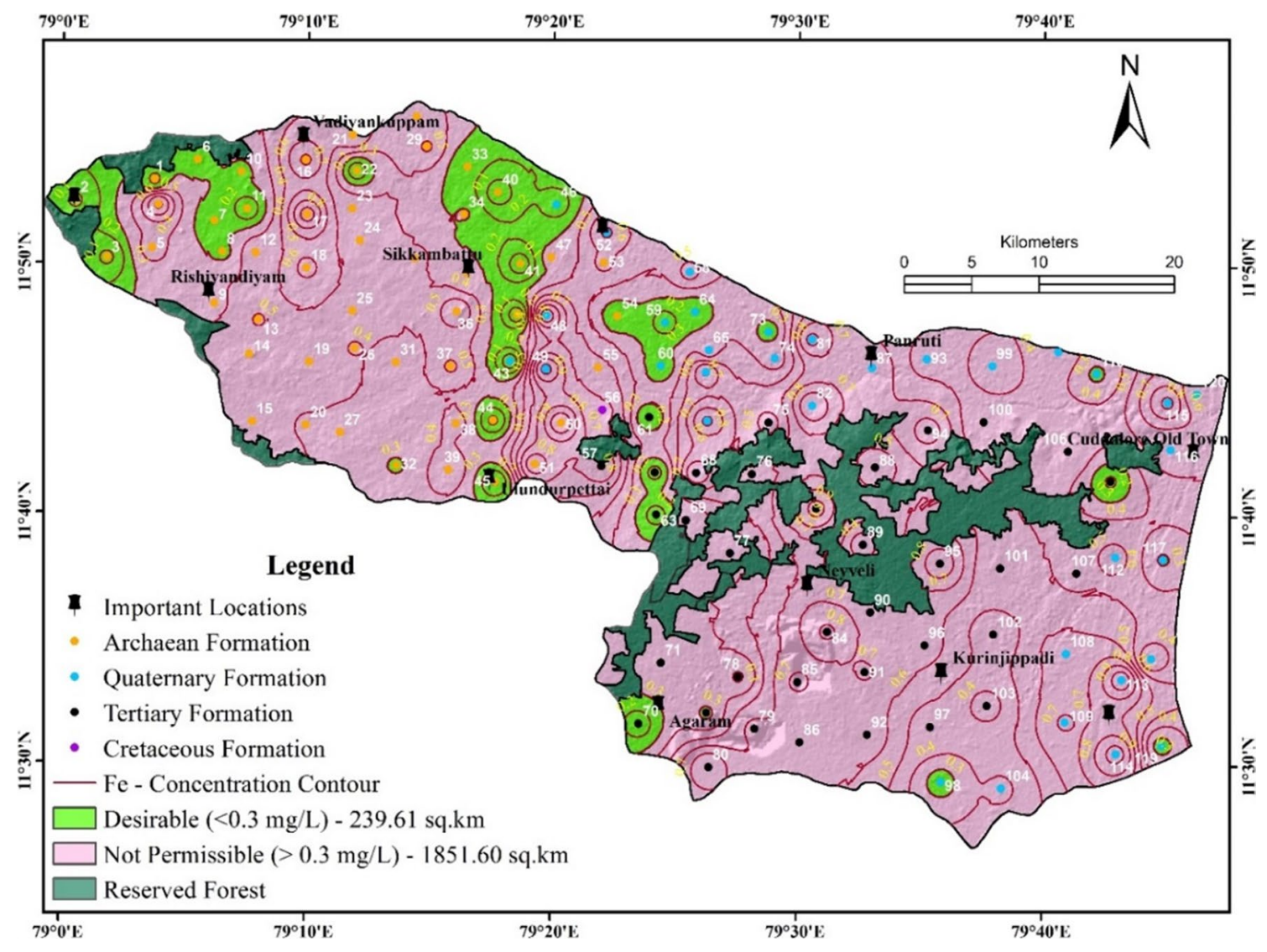

Fig. 11 Spatial variation with contour map of iron in groundwater

Iron and Nickel concentrations are detected as Archaean $>$ Quaternary $>$ Tertiary $>$ Cretaceous formation. High iron concentration is recorded in Archaean formation but, highest average values noticed in cretaceous formation. High concentration and average value of Nickel was observed in Archaean formation.

Copper concentration in various formations can be arranged as Archaean $>$ Tertiary $>$ Quaternary $>$ Cretaceous formation. High copper concentration is recorded in Archaean formation but, highest average values noticed in cretaceous formation.

\section{Taxonomy diagram}

Taxonomy diagram consists total concentration of trace metals $\mathrm{Vs} \mathrm{pH}$ of the groundwater. This graphical interpretation (Fig. 14) showing the entire groundwater samples comes under 'Near neutral high metal" categories. The heavy metal pollution is increased by industrial effluent, domestic sewages (Venkatramanan et al. 2014).

\section{Spatial multi-criteria evaluation (SMCE) analysis for risk hazardous of groundwater}

The heavy metal contamination has a significant role in human health hazardous. Heavy metals in groundwater are analyzed and their sources and impacts are identified using SMCE method and risk assessment (Imran Ahmad et al. 2019; Vasant Madhav Wagh et al. 2019). As shown in Table 8, Spatial Multi-Criteria Evaluation Rank of Risk Hazardous of Groundwater is generated. SMCE overlay analysis is made using all the thematic layers and finally, to find out risk and high risk groundwater zones of Gadilam River basin (Fig. 15). 


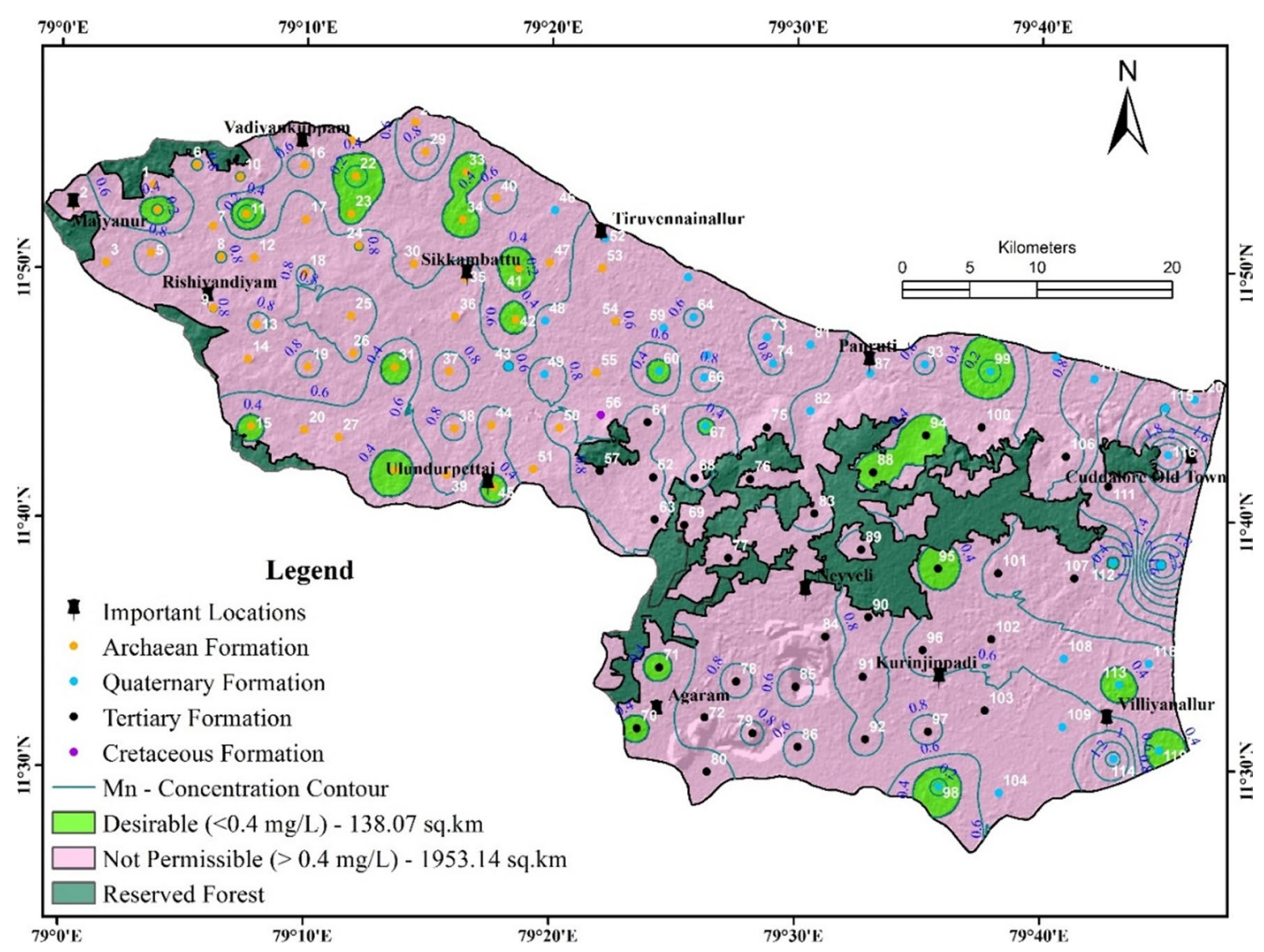

Fig. 12 Spatial variation with contour map of manganese in groundwater

Overall analysis reveals that the 27 samples (Archaean-13, Quaternary-11, Tertiary-2 and Cretaceous-1) samples come under 'High risk hazardous' zone. 65 groundwater samples (Archaean-24, Quaternary-16 and Tertiary-25) come under 'Risk hazardous' zones. Twentyeight groundwater sites (Archaean-13, Quaternary-7 and Tertiary-8) come under 'No problem' zones. The 'High risk hazardous' zones are noticed in dense residential area in the Archaean formation, lineaments intersection with river portion and sea shore area in Quaternary formation, nearby SIPCOT industry and in Lignite mining area in Tertiary formation (Varol 2019; Barra-Rocha et al. 2019; Hou et al. 2019; Adimalla 2020).

\section{Spatial validation of research results}

The present research has been undertaken in order to find out the groundwater quality for heavy metal contamination using GIS Techniques in Gadilam River basin. This research results are validated with land use/land cover map (Fig. 16). Nickel (Ni), Chromium (Cr), Lead (Pb) and Cobalt (Co) concentrations for all the samples are fall in the category of 'not permissible' with respect to WHO (2017). Most of the samples are not permissible with respect of WHO limit and $11 \%$ of the sample with in permissible limit for Iron $\left(\mathrm{Fe}^{2+}+\mathrm{Fe}^{3+}\right)$. The samples that fall within permissible category are taken from shallow depth wells (within $5 \mathrm{~m})$.

The higher $\mathrm{Zn}$ values are observed in Tertiary formation and one sample in Quaternary formation. Locations of Tertiary formation are validated with land use/land cover map. Not permissible category sample wells are located around mining area (Lignite mines). One sample (Quaternary formation) well is located in Beach (Seashore) area.

Most of the samples are not permissible with respect to WHO limit and twenty-one samples value lies within permissible limit for Manganese (Mn). This permissible sample wells are located nearby water bodies (Fig. 16). 


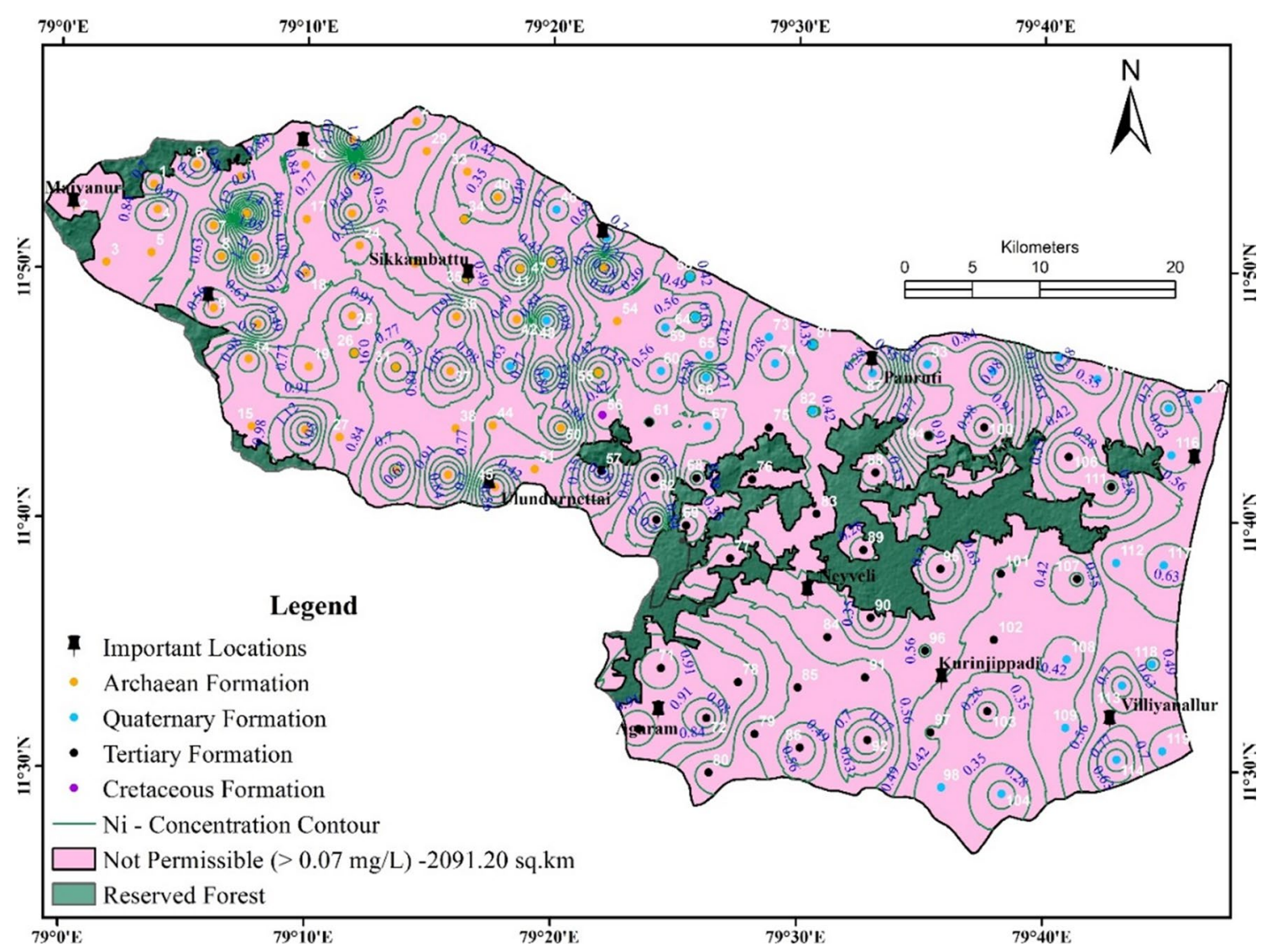

Fig. 13 Spatial variation with contour map of nickel in groundwater

Table 2 Correlation analysis of Archaean groundwater samples

Table 3 Correlation analysis of quaternary formation

\begin{tabular}{|c|c|c|c|c|c|c|c|c|}
\hline \multirow[t]{2}{*}{ Variable } & \multicolumn{8}{|c|}{50 samples (Archaean formation) } \\
\hline & $\mathrm{Zn}$ & $\mathrm{Cr}$ & $\mathrm{Cu}$ & $\mathrm{Pb}$ & Co & $\mathrm{Fe}$ & $\mathrm{Mn}$ & $\mathrm{Ni}$ \\
\hline $\mathrm{Zn}$ & 1.00 & & & & & & & \\
\hline $\mathrm{Cr}$ & -0.19 & 1.00 & & & & & & \\
\hline $\mathrm{Cu}$ & 0.13 & -0.17 & 1.00 & & & & & \\
\hline $\mathrm{Pb}$ & -0.18 & 0.11 & 0.11 & 1.00 & & & & \\
\hline Co & 0.31 & -0.01 & -0.26 & 0.30 & 1.00 & & & \\
\hline $\mathrm{Fe}$ & 0.05 & 0.04 & -0.02 & -0.13 & -0.04 & 1.00 & & \\
\hline $\mathrm{Mn}$ & -0.21 & -0.11 & -0.25 & -0.10 & 0.00 & 0.41 & 1.00 & \\
\hline $\mathrm{Ni}$ & 0.27 & -0.09 & -0.01 & -0.39 & 0.07 & 0.32 & 0.06 & 1.00 \\
\hline
\end{tabular}

\begin{tabular}{|c|c|c|c|c|c|c|c|c|}
\hline \multirow[t]{2}{*}{ Variable } & \multicolumn{8}{|c|}{34 Samples (quaternary formation) } \\
\hline & $\mathrm{Zn}$ & $\mathrm{Cr}$ & $\mathrm{Cu}$ & $\mathrm{Pb}$ & Co & $\mathrm{Fe}$ & Mn & $\mathrm{Ni}$ \\
\hline $\mathrm{Zn}$ & 1.00 & & & & & & & \\
\hline $\mathrm{Cr}$ & 0.06 & 1.00 & & & & & & \\
\hline $\mathrm{Cu}$ & 0.07 & 0.02 & 1.00 & & & & & \\
\hline $\mathrm{Pb}$ & -0.15 & -0.26 & -0.30 & 1.00 & & & & \\
\hline Co & 0.11 & -0.41 & 0.21 & 0.20 & 1.00 & & & \\
\hline $\mathrm{Fe}$ & 0.03 & -0.02 & -0.11 & 0.09 & -0.25 & 1.00 & & \\
\hline $\mathrm{Mn}$ & -0.27 & 0.02 & 0.02 & -0.35 & -0.21 & 0.11 & 1.00 & \\
\hline $\mathrm{Ni}$ & -0.11 & 0.14 & -0.15 & -0.32 & -0.03 & 0.18 & 0.09 & 1.00 \\
\hline
\end{tabular}


Table 4 Correlation analysis of groundwater samples

Table 5 Factor analysis for the Archaean formation groundwater samples (varimax rotated)

Table 6 Factor analysis for the quaternary formation groundwater samples (varimax rotated)

\begin{tabular}{|c|c|c|c|c|c|c|c|c|}
\hline \multirow[t]{2}{*}{ Variable } & \multicolumn{8}{|c|}{ Marked correlations are significant at $p<.05000, N=35$ (tertiary formation) } \\
\hline & $\mathrm{Zn}$ & $\mathrm{Cr}$ & $\mathrm{Cu}$ & $\mathrm{Pb}$ & Co & $\mathrm{Fe}$ & $\mathrm{Mn}$ & $\mathrm{Ni}$ \\
\hline $\mathrm{Zn}$ & 1.00 & & & & & & & \\
\hline $\mathrm{Cr}$ & -0.16 & 1.00 & & & & & & \\
\hline $\mathrm{Cu}$ & -0.01 & -0.00 & 1.00 & & & & & \\
\hline $\mathrm{Pb}$ & 0.02 & -0.00 & -0.10 & 1.00 & & & & \\
\hline Co & 0.19 & 0.05 & -0.18 & 0.27 & 1.00 & & & \\
\hline $\mathrm{Fe}$ & 0.21 & -0.38 & 0.04 & -0.13 & 0.00 & 1.00 & & \\
\hline $\mathrm{Mn}$ & -0.14 & 0.18 & -0.12 & 0.15 & 0.21 & -0.30 & 1.00 & \\
\hline $\mathrm{Ni}$ & -0.04 & 0.22 & 0.04 & 0.10 & 0.06 & -0.16 & -0.25 & 1.00 \\
\hline
\end{tabular}

\begin{tabular}{llcll}
\hline Variables & Factor-1 & Factor-2 & Factor-3 & Factor-4 \\
\hline $\mathrm{Zn}$ & -0.347727 & 0.728486 & -0.315952 & -0.025022 \\
$\mathrm{Cr}$ & 0.258315 & -0.355990 & -0.133928 & -0.676617 \\
$\mathrm{Cu}$ & 0.137455 & 0.500039 & 0.537319 & 0.363089 \\
$\mathrm{~Pb}$ & 0.654937 & -0.085777 & -0.353493 & 0.417987 \\
$\mathrm{Co}$ & 0.026156 & 0.187294 & -0.911964 & 0.125999 \\
$\mathrm{Fe}$ & -0.642379 & -0.322805 & -0.030997 & 0.207126 \\
$\mathrm{Mn}$ & -0.449220 & -0.651687 & -0.089792 & 0.422039 \\
$\mathrm{Ni}$ & -0.746262 & 0.230877 & -0.061632 & -0.216764 \\
Expl. var & 1.807517 & 1.532100 & 1.375933 & 1.048864 \\
$\mathrm{Prp}$. totl & 0.225940 & 0.191512 & 0.171992 & 0.131108 \\
Eigenvalue & 1.807517 & 1.5321 & 1.375933 & 1.048864 \\
$\%$ Total variance & 22.59396 & 19.15125 & 17.19916 & 13.1108 \\
Cumulative Eigenvalue & 1.807517 & 3.339617 & 4.71555 & 5.764414 \\
Cumulative \% & 22.59396 & 41.74521 & 58.94437 & 72.05517 \\
\hline
\end{tabular}

\begin{tabular}{llcrr}
\hline Variables & Factor 1 & \multicolumn{1}{l}{ Factor 2 } & \multicolumn{1}{c}{ Factor 3 } & \multicolumn{1}{c}{ Factor 4 } \\
\hline $\mathrm{Zn}$ & -0.169065 & 0.387831 & 0.678380 & 0.286104 \\
$\mathrm{Cr}$ & 0.572434 & 0.150816 & 0.507037 & -0.317343 \\
$\mathrm{Cu}$ & -0.060550 & 0.752038 & -0.192851 & -0.089754 \\
$\mathrm{~Pb}$ & -0.643694 & -0.621801 & 0.065668 & -0.169755 \\
$\mathrm{Co}$ & -0.679474 & 0.310294 & -0.281389 & 0.404946 \\
$\mathrm{Fe}$ & 0.287644 & -0.480519 & 0.139401 & 0.378942 \\
$\mathrm{Mn}$ & 0.564892 & 0.006664 & -0.600688 & -0.125631 \\
$\mathrm{Ni}$ & 0.492393 & -0.061305 & -0.075006 & 0.715772 \\
Expl. var & 1.880250 & 1.456339 & 1.223855 & 1.055126 \\
$\mathrm{Prp}$ totl & 0.235031 & 0.182042 & 0.152982 & 0.131891 \\
Eigenvalue & 1.88025 & 1.456339 & 1.223855 & 1.055126 \\
$\%$ Total variance & 23.50312 & 18.20424 & 15.29818 & 13.18907 \\
Cumulative Eigenvalue & 1.88025 & 3.336589 & 4.560444 & 5.61557 \\
Cumulative \% & 23.50312 & 41.70736 & 57.00555 & 70.19462 \\
\hline
\end{tabular}


Table 7 Factor analysis for the tertiary formation groundwater samples (varimax rotated)

\begin{tabular}{llrr}
\hline Variables & Factor 1 & \multicolumn{1}{l}{ Factor 2} & \multicolumn{1}{l}{ Factor 3 } \\
\hline $\mathrm{Zn}$ & -0.550896 & 0.383770 & 0.122964 \\
$\mathrm{Cr}$ & 0.697119 & 0.017699 & 0.266501 \\
$\mathrm{Cu}$ & -0.058900 & -0.442643 & 0.233586 \\
$\mathrm{~Pb}$ & 0.133477 & 0.643146 & 0.094163 \\
$\mathrm{Co}$ & -0.015187 & 0.798748 & 0.004767 \\
$\mathrm{Fe}$ & -0.786719 & -0.069006 & -0.066970 \\
$\mathrm{Mn}$ & 0.520840 & 0.299650 & -0.614615 \\
$\mathrm{Ni}$ & 0.201613 & 0.114975 & 0.865136 \\
Expl. var & 1.741826 & 1.502932 & 1.280292 \\
$\mathrm{Prp}$. totl & 0.217728 & 0.187867 & 0.160037 \\
Eigenvalue & 1.802139 & 1.469365 & 1.253546 \\
\% Total variance & 22.52673 & 18.36706 & 15.66933 \\
Cumulative Eigenvalue & 1.802139 & 3.271504 & 4.52505 \\
Cumulative \% & 22.52673 & 40.8938 & 56.56313 \\
\hline
\end{tabular}

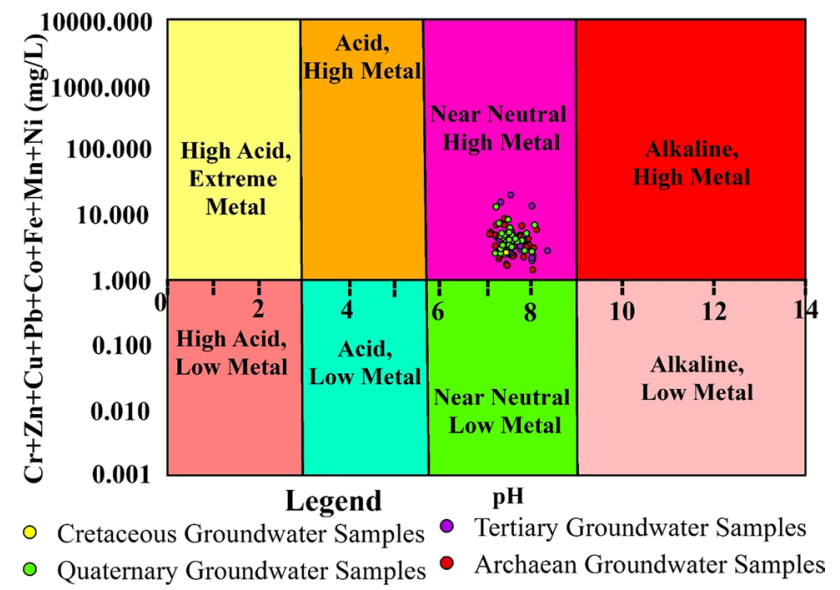

Fig. 14 Taxonomy effect plot with respect to heavy metals vs $\mathrm{pH}$

\section{Conclusion}

The copper concentration of the groundwater is within the limits as specified as less than $2 \mathrm{mg} / \mathrm{l} .96 .22 \%$ of the study area come under permissible limit of zinc. Chromium, lead, cobalt, nickel concentrations are high (above the permissible limit) in all the samples. The $96.22 \%$ of the study area is less than $3 \mathrm{mg} / \mathrm{l}$ of zinc. The manganese concentrations are higher in $93.40 \%$ of the area and fall under not permissible limit for human consumption as per WHO standards.

Taxonomy diagram showing the entire groundwater samples comes under "Near neutral high metal" categories. The heavy metal pollution is increased by industrial effluent and domestic sewages.

Overview of the heavy metal concentrations of groundwater for various geological formations is observed as follows. Zinc concentration are gradually decreasing from Tertiary $>$ Quaternary $>$ Archaean $>$ Cretaceous formation. Chromium, lead and cobalt concentrations are arranged as Tertiary $>$ Archaean $>$ Quaternary $>$ Cretaceous formation. High chromium, lead and cobalt concentrations are recorded in tertiary formation. Manganese concentrations are Quaternary $>$ Tertiary $>$ Archaean $>$ Cretaceous formation. High manganese concentration is recorded in quaternary formation. Iron and Nickel concentrations are observed as Archaean $>$ Quaternary $>$ Tertiary $>$ Cretaceous formation. High iron concentration is recorded in Archaean formation. Copper concentration is marked as Archaean $>$ Tertiary $>$ Quaternary $>$ Cretaceous formation. High copper concentration is recorded in Archaean formation. 
Table 8 Spatial multi-criteria Evaluation rank on risk hazardous of groundwater

\begin{tabular}{lllll}
\hline $\begin{array}{l}\text { General parameters and heavy } \\
\text { metals }\end{array}$ & $\begin{array}{l}\text { Desirable values } \\
\text { for WHO-2017 }\end{array}$ & $\begin{array}{l}\text { Desirable values } \\
\text { for BIS-2012 }\end{array}$ & $\begin{array}{l}\text { Risk Hazardous for present study } \\
\text { Spatial multi-criteria evalua- } \\
\text { tion rank on risk hazardous of } \\
\text { groundwater }\end{array}$ \\
\hline $\mathrm{pH}$ & $6.5-8.5$ & No relaxation & $8.5-9.2$ & 5 \\
Electrical conductivity $(\mathrm{EC})$ & $1500(\mu \mathrm{mohs} / \mathrm{cm}$ & No relaxation & $1500-3000(\mu \mathrm{mohs} / \mathrm{cm}$ & 5 \\
TDS & $500-1500 \mathrm{mg} / \mathrm{L}$ & No relaxation & $1500-3000 \mathrm{mg} / \mathrm{L}$ & 5 \\
Zinc $(\mathrm{Zn})$ & $3 \mathrm{mg} / \mathrm{L}$ & $15 \mathrm{mg} / \mathrm{L}$ & Above $15 \mathrm{mg} / \mathrm{L}$ & 8 \\
Chromium $(\mathrm{Cr})$ & $0.05 \mathrm{mg} / \mathrm{L}$ & No relaxation & Above $0.05 \mathrm{mg} / \mathrm{L}$ & 10 \\
Copper $(\mathrm{Cu})$ & $2 \mathrm{mg} / \mathrm{L}$ & $15 \mathrm{mg} / \mathrm{L}$ & Above $15 \mathrm{mg} / \mathrm{L}$ & 8 \\
Lead $(\mathrm{Pb})$ & $0.01 \mathrm{mg} / \mathrm{L}$ & $0.05 \mathrm{mg} / \mathrm{L}$ & Above $0.05 \mathrm{mg} / \mathrm{L}$ & 8 \\
Cobalt $(\mathrm{Co})$ & $0.05 \mathrm{mg} / \mathrm{L}$ & No relaxation & Above $0.5 \mathrm{mg} / \mathrm{L}$ & 10 \\
Iron $(\mathrm{Fe})$ & $0.3 \mathrm{mg} / \mathrm{L}$ & $1.0 \mathrm{mg} / \mathrm{L}$ & Above $1.0 \mathrm{mg} / \mathrm{L}$ & 8 \\
Manganese $(\mathrm{Mn})$ & $0.4 \mathrm{mg} / \mathrm{L}$ & No relaxation & Above $0.4 \mathrm{mg} / \mathrm{L}$ & 10 \\
Nickel $(\mathrm{Ni})$ & $0.07 \mathrm{mg} / \mathrm{L}$ & No relaxation & Above $0.07 \mathrm{mg} / \mathrm{L}$ & 10 \\
Total rank & & & $87 / 110$ \\
\hline
\end{tabular}

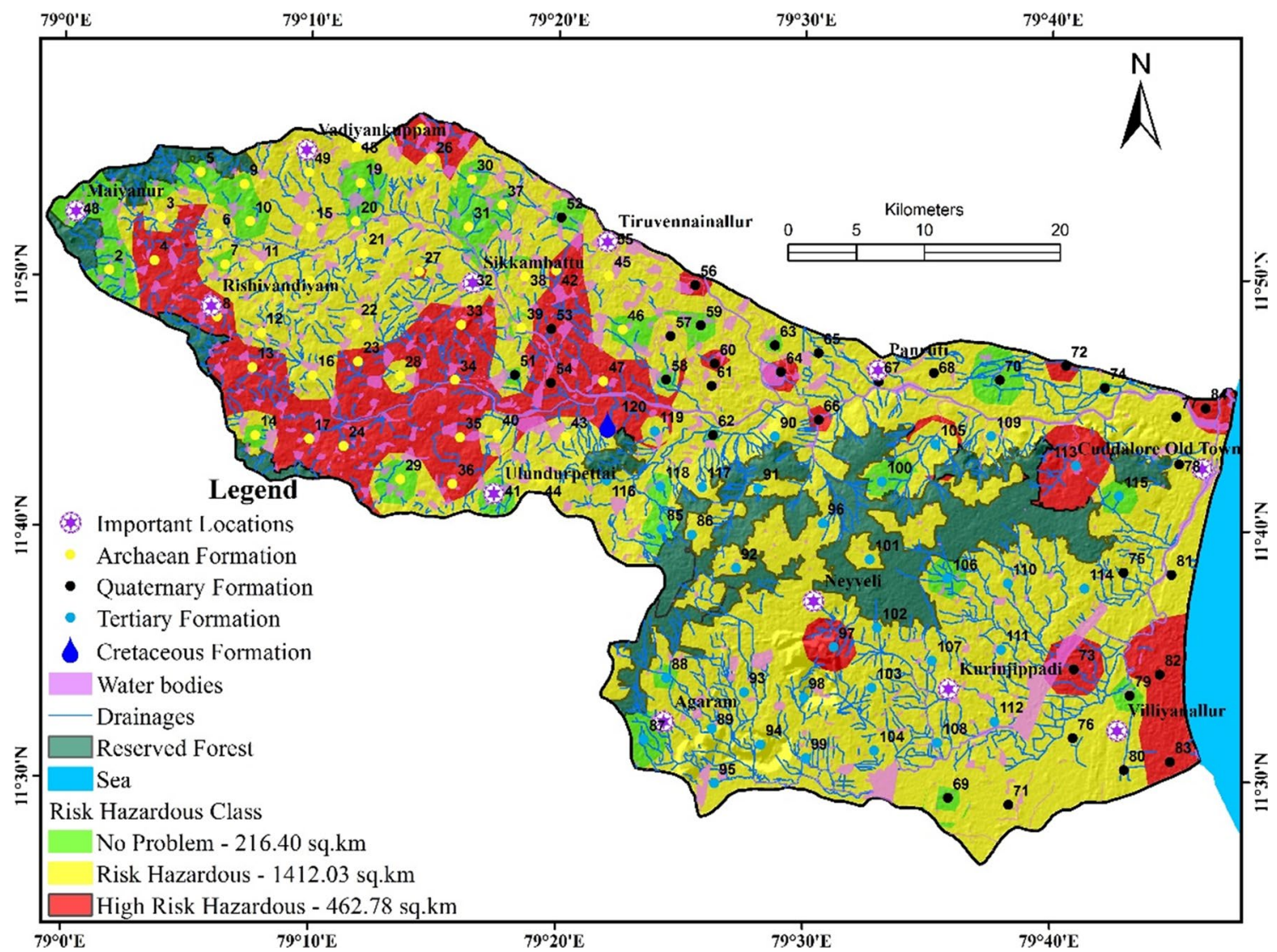

Fig. 15 Heavy metal health hazardous zonation map 


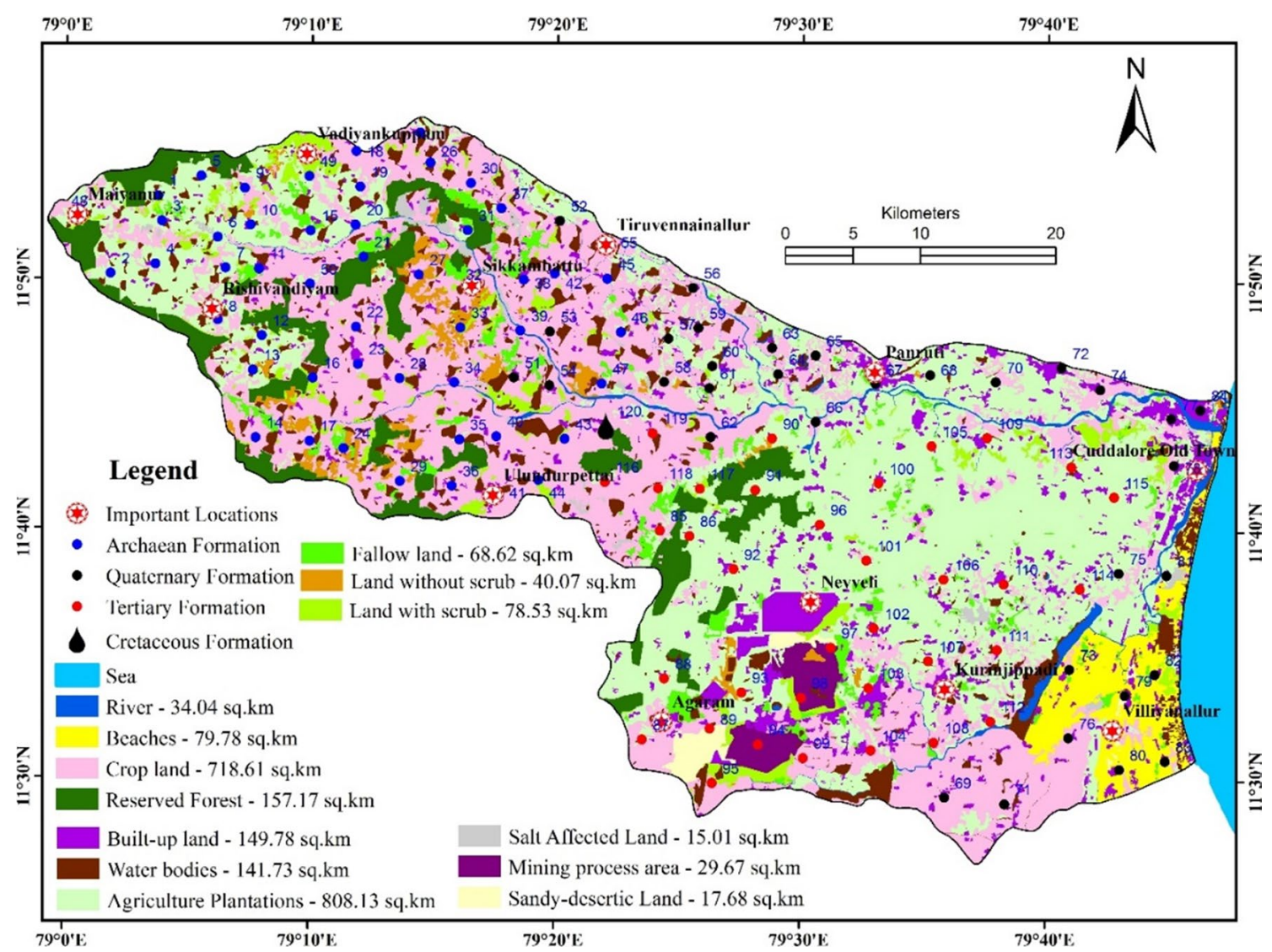

Fig. 16 Land use/land cover with geological formation wise groundwater sample locations

In Archaean formation, factor and correlation matrix shows that $\mathrm{Pb}, \mathrm{Mn}, \mathrm{Cu}$ and $\mathrm{Fe}$ metals from wastewater of various industries and Iron ores. Quaternary formation reveals that the $\mathrm{Cr}, \mathrm{Mn}, \mathrm{Ni}$ and $\mathrm{Fe}$ indicating leaching of secondary salts, which are also present in seawater. Tertiary formation shows a higher $\mathrm{Cr}$ and $\mathrm{Mn}$ that may be due to the Mining and associated activities.

Groundwater heavy metals risk assessment analysis using SMCE method shows that three categories of zones viz., by 'No problem,' 'Risk hazardous' and 'High risk hazardous. The 'High risk hazardous' zones are noticed in dense residential area in the Archaean formation, lineaments intersection with river portion and sea shore area in Quaternary formation and nearby SIPCOT industry and Lignite mining area in Tertiary formation.

Overall groundwater class is classified as unacceptable for drinking purposes in all the samples. The heavy metals concentration in groundwater is due to pollution from various sources of industrial wastes, agricultural and sewage runoff.
This research results are validated with land use/land cover. Our results that EC and TDS high values are observed in urban and sea shore area, which is due to the infiltration of domestic wastewater and sea water intrusion. High concentration of heavy metals in groundwater is noticed in dense residential come industrial areas, mining area and sea shore area. In many regions, the groundwater pollution is remarkably impacted by the assorted land use types.

Authors' contributions Thirukumaran has conceived of the study, formulated its design, coordinated the conduct of the study including data collection, performed the statistical analysis and interpreted the data, and drafted the manuscript; Rizwan has participated in the design of the study, assisted in interpreting the data, and helped to draft the manuscript; Suresh has participated in the design of the study, assisted in interpreting the data, and helped to draft the manuscript. All authors read and approved the final manuscript.

Funding This study was not funded by any agencies. 


\section{Declarations}

Conflict of interest The authors report no conflicts of interest.

Ethical standards This study was in 'Compliance with Ethical Standards.' 'For this type of study formal consent is not required.'

Ethical conduct This chapter does not contain any studies with human participants or animals performed by any of the authors." "Informed consent was obtained from all individual participants included in the study.

Open Access This article is licensed under a Creative Commons Attribution 4.0 International License, which permits use, sharing, adaptation, distribution and reproduction in any medium or format, as long as you give appropriate credit to the original author(s) and the source, provide a link to the Creative Commons licence, and indicate if changes were made. The images or other third party material in this article are included in the article's Creative Commons licence, unless indicated otherwise in a credit line to the material. If material is not included in the article's Creative Commons licence and your intended use is not permitted by statutory regulation or exceeds the permitted use, you will need to obtain permission directly from the copyright holder. To view a copy of this licence, visit http://creativecommons.org/licenses/by/4.0/.

\section{References}

Abou Zakhem B, Hafez R (2015) Heavy metal pollution index for groundwater quality assessment in Damascus Oasis, Syria. Environ Earth Sci 73:6591-6600. https://doi.org/10.1007/ s12665-014-3882-5

Adhikary PP, Chandrasekharan H, Chakraborty D, Kamble K (2010) Assessment of groundwater pollution in West Delhi, India using geostatistical approach. Environ Monit Assess 167(1-4):599-615

Adimalla N (2020) Spatial distribution, exposure, and potential health risk assessment from nitrate in drinking water from semi-arid region of South India. Hum Ecol Risk Assess 26(2):310-334. https ://doi.org/https://doi.org/10.1080/10807 039.2018.15083 29

Adimalla N (2019) Heavy metals contamination in urban surface soils of Medak province, India, and its risk assessment and spatial distribution. Environ Geochem Health. https://doi.org/10. 1007/s10653-019-00270-1

Ahmad I, Dar MA, Andualem TG, Teka AH, Tolosa AT (2019) GISBased Multi-criteria Evaluation for Deciphering of Groundwater Potential. J Ind Soc Remote Sens. https://doi.org/10.1007/ s12524-019-01078-3

Alsbou EME, Al-Khashman OA (2018) Heavy metal concentrations in roadside soil and street dust from Petra region, Jordan. Environ Monit Assess 190:48-60

American Public Health Association (APHA) (2012) Standard methods for the examination of water and wastewater, 27th edn. APHHA, Washington

Antoniadis V, Levizou E, Shaheen SM, Ok YS, Sebastian A, Baum C, Prasad MNV, Wenzel WW, Rinklebe J (2017) Trace elements in the soil-plant interface: phytoavailability, translocation, and phytoremediation-a review. Earth Sci Rev 171:621-645

Asghari FB, Mohammadi AA, Dehghani MH, Yousefi M (2018) Data on assessment of groundwater quality with application of ArcGIS in Zanjan. Iran Data Brief 18:375

Banerjee US, Gupta S (2013) Impact of industrial waste effluents on river damodar adjacent to Durgapur industrial complex, West Bengal, India. Environ Monit Assess 185:2083-2094
Barra-Rocha CH, Fernandes-Costa H, Pimenta-Azevedo L (2019) Heavy metals in the São Mateus Stream Basin, Peixe River Basin, Paraiba do Sul River Basin, Brazil. Ambient Agua Interdiscip J Appl Sci 14:1-13

Belkhiria L, Mounib L, Naranyc TS, Tiria A (2017) Evaluation of potential health risk of heavy metals in groundwater using the integration of indicator kriging and multivariate statistical methods. Groundw Sustain Dev 4:12-22

Bhuiyan MAH, Parvez L, Islam MA, Dampare SB, Suzuki S (2010) Heavy metal pollution of coal mine affected agricultural soils in the northern part of Bangladesh. J Hazard Mater 173:384-392

BIS (Bureau of Indian Standards) (2012). Indian standard for drinking water-specification, second edition, IS 10500: 2012, Drinking Water Sectional Committee, FAD 25. New Delhi, India

Brindha K, Elango L (2013) Occurrence of uranium in groundwater of a shallow granitic aquifer and its suitability for domestic use in southern India. J Radioanal Nuclear Chem 295:357-367

Bridges RL, Cho CS, Beck MR, Gessner BD, Tower SS (2020) F-18 FDG PET brain imaging in symptomatic arthroprosthetic cobaltism. Eur J Nucl Med Mol Imaging 47:1961-1970. https://doi. org/10.1007/s00259-019-04648-2

Dahaan-Al S, Al-Ansari N, Knutsson S (2016) Influence of groundwater hypothetical salts on electrical conductivity, total dissolved solids. Engineering 8(11):823-830

Dahl C, Sogaard AJ, Tell GS, Flaten TP, Hongve D, Omsland TK, Aamodt G (2014) Do cadmium, lead, and aluminum in drinking water increase the risk of hip fractures? A NOREPOS Study. Biol Trace Elem Res 157(1):14-23

Dixit S, Tiwari S (2008) Impact Assessment of heavy metal pollution of shahpura Lake, Bhopal. India Int J Environ Res 2(1):37-42

El Amari K, Valera P, Hibti M, Pretti S, Marcello A, Essarraj S (2014) Impact of mine tailings on surrounding soils and ground water: case of Kettaraold mine, Morocco. J Afr Earth Sci 100:437-449

Engwa GA, Ferdinand PU, Nwalo FN, Unachukwu MN (2018) Mechanism and effects of heavy metal toxicity in humans, poisoning in the modern world-new tricks for an old dog? Ozgur Karcioglu and Banu Arslan. IntechOpen. https://doi.org/10.5772/intechopen. 82511

Gope M, Reginald EM, Joshy G, Raza GRH, Srinivasan B (2017) Bioavailability and health risk of some potentially toxic elements $(\mathrm{Cd}, \mathrm{Cu}, \mathrm{Pb}$ and $\mathrm{Zn})$ in street dust of Asansol, India. Ecotoxicol Environ Saf 138:231-241

Haloi N, Sarma HP (2012) Heavy metal contaminations in the groundwater of Brahmaputra flood plain: an assessment of water quality in Barpeta District, Assam (India). Environ Monit Assess 184(10):6229-6237

Hou S, Zheng N, Tang L, Ji X, Li Y, Hua X (2019) Pollution characteristics, sources, and health risk assessment of human exposure to $\mathrm{Cu}, \mathrm{Zn}, \mathrm{Cd}$ and $\mathrm{Pb}$ pollution in urban street dust across China between 2009 and 2018. Environ Int 128:430-437

Islam MS, Khanam MS, Sarker NI (2018) Health risk assessment of metals transfer from soil to the edible part of some vegetables grown in Patuakhali province of Bangladesh. Arch Agric Environ Sci 3:187-197

Kannan D, Mani N (2015) Chemical analysis of groundwater from various parts of Thanjavur District, Tamil Nadu (India). ILCPA $5(6): 18-30$

Krishna AK, Mohan KR (2016) Distribution, correlation, ecological and health risk assessment of heavy metal contamination in surface soils around an industrial area, Hyderabad, India. Environ Earth Sci 75:411-427

Kumar PJS (2014) Evolution of groundwater chemistry in and around Vaniyambadi industrial area: differentiating the natural and anthropogenic sources of contamination. Chem Erde 74:641-651. https://doi.org/10.1016/j.chemer.2014.02.002 
Kumar PJS, Delson PD, Babu PT (2012) Appraisal of heavy metals in groundwater in Chennai City Using a HPI model. Bull Environ Contam Toxicol 89:793-798

Kumar A, Subrahmanyam G, Mondal R, Cabral-Pinto MMS, Shabnam AA, Jigyasu DK, Malyan SK, Fagodiya RK, Khan SA, Yu ZG (2021) Bio-remediation approaches for alleviation of cadmium contamination in natural resources. Chemosphere. https:// doi.org/10.1016/j.chemosphere.2020.128855

Kupwade RV, Langade AD (2013) Pre and post monsoon monitoring of groundwater quality in region near Kupwad MIDC, sangli Maharashtra. Int J Chemtech Res 5(5):2291-2294

Mahapatra SR, Venugopal T, Shanmugasundaram A, Giridharan L, Jayaprakash M (2020) Heavy metal index and geographical information system (GIS) approach to study heavy metal contamination: a case study of north Chennai groundwater. Appl Water Sci 10:238. https://doi.org/10.1007/s13201-020-01321-0

Mahmoud S, ShahubMahmoud S, IbrahimMaie I, Algammal M, Abdelgalil M, Alatrash S (2016) Seasonal analysis of physicochemical parameters of ground and surface water in Kaam area Libya. JESTFT. 10(6):46-50

Mohamed Sihabudeen M, Abbas Ali A, Zahir HA (2015) Monitoring the quality of groundwater pollution in and around Trichy town, Tamilnadu. Der Chemica Sinica 6(4):39-42

Mohiuddin KM, Alam MM, Ahmed I, Chowdhury AK (2015) Heavy metal pollution load in sediment samples of the Buriganga river in Bangladesh. J Bangladesh Agril Univ 13(2):229-238

Momodu M, Anyakora C (2010) Heavy metal contamination of groundwater: the Surulere case study. Res J Environ Earth Sci 2:39-43

Muhammad N, Nafees M (2018) Geo-chemical investigation and health risk assessment of potential toxic elements in industrial wastewater irrigated soil: a geo-statistical approach. J Biodiv Environ Sci 12:367-380

Muthusaravanan S, Sivarajasekar N, Vivek JS, Paramasivan T, Naushad M, Prakashmaran J, Gayathri V, Al-Duaij OK (2018) Phytoremediation of heavy metals: mechanisms, methods and enhancements. Environ Chem Lett 16:1339-1359

Ogbomida ET, Nakayama S, Bortey-Sam N, Oroszlany B, Tongo I, Enuneku AA, Ogbeide O, Ainerua MO, Fasipe IP, Ezemonye LI, Mizukawa H, Ikenaka Y, Ikenaka M, Ishizuka., (2018) Accumulation patterns and risk assessment of metals and metalloid in muscle and official of free-range chickens, cattle and goat in Benin City, Nigeria. Ecotoxicol Environ Saf 151:98-108

Panigrahy BP, Singh PK, Tiwari AK, Kumar B, Kumar A (2015) Assessment of heavy metal pollution index for groundwater around Jharia coalfield region, India. J Biodivers Environ Sci 6:33-39

Panthri, M., Gupta, M., (2019). Plausible strategies to reduce arsenic accumulation in rice. Adv Rice Res Abiotic Stress Tolerance. Woodhead Publishing, pp 371-384.

Papachristodoulou C, Stamoulis K, Tsakos P, Vougidou C, Vozikis V, Papadopoulou C, Ioannides K (2015) Liver concentrations of copper, zinc, iron and molybdenum in sheep and goats from Northern Greece, determined by energy-dispersive $\mathrm{X}$-ray fluorescence spectrometry. Bull Environ Contam Toxicol 94(4):460-467

Pathak AK, Kumar R, Kumar P, Yadav S (2015) Sources apportionment and spatiotemporal changes in metal pollution in surface and sub-surface soils of a mixed type industrial area in India. J Geochem Explor 159:169-177

Paul R, Brindha K, Gowrisankar G, Tan ML, Singh MK (2019) Identification of hydrogeochemical processes controlling groundwater quality in Tripura, Northeast India using evaluation indices, GIS, and multivariate statistical methods. Environ Earth Sci 78:470. https://doi.org/10.1007/s12665-019-8479-6

Philip Njoku Obasi and Bennard Benedict Akudinobi (2020) Potential health risk and levels of heavy metals in water resources of lead-zinc mining communities of Abakaliki, southeast Nigeria. Appl Water Sci 10:184. https://doi.org/10.1007/ s13201-020-01233-z

Pobi KK, Nayek S, Saha RN (2017) Assessment of heavy metals in water, sediment and adjacent soil of a contaminated channel in durgapur industrial zone, West Bengal, India. Int J Ecol Environ Sci 43(4):275-285

Pobi KK, Satpati S, Dutta S, Nayek S, Saha RN, Gupta S (2019) Sources evaluation and ecological risk assessment of heavy metals accumulated within a natural stream of Durgapur industrial zone, India, by using multivariate analysis and pollution indices. Appl Water Sci 9:58-73

Purushotham D, Rashid M, Lone MA, Rao AN, Ahmed S, Nagaiah E, Dar FA (2013) Environmental impact assessment of air and heavy metal concentration in groundwater of Maheshwaram watershed, Ranga Reddy district, Andhra Pradesh. J Geol Soc India 81(3):385-396

Qasemi M, Shams M, Sajjadi SA, Farhang M, Erfanpoor S, Yousefi M, Zarei A, Afsharnia M (2019) Cadmium in groundwater consumed in the rural areas of Gonabad and Bajestan, Iran: occurrence and health risk assessment. Biol Trace Elem Res 192:106-115

Rahman SH, Khanam D, Adyel TM, Islam MS, Ahsan MA, Akbor MA (2012) Assessment of heavy metal contamination of agricultural soil around Dhaka Export Processing Zone (DEPZ), Bangladesh: implication of seasonal variation and indices. Appl Sci 2:584-601

Rai PK (2008) Phytoremediation of $\mathrm{Hg}$ and Cd from industrial effluents using an aquatic free floating macrophyte Azolla pinnata. Int J Phytoremediation 10:430-439

Ravindra K, Mor S (2019) Distribution and health risk assessment of arsenic and selected heavy metals in Groundwater of Chandigarh, India. Environ Pollut 250:820-830

Ravindra K, Thind PS, Mor S, Singh T, Mor S (2019) Evaluation of groundwater contamination in Chandigarh: source identification and health risk assessment. Environ Pollut 255:113062

Redvan G, Nasim SH (2017) Study on groundwater quality using geographic information system (GIS), case study: Ardabil. Iran. Civil Engi J 3(9):779-793. https://doi.org/10.21859/cej-030914

Rezaei A, Hassani H, Hassani S, Jabbari N, Fard Mousavi SB, Rezaei S (2019) Evaluation of groundwater quality and heavy metal pollution indices in Bazman basin, southeastern Iran. Groundw Sustain Dev 9:100245

Rostami R, Zarei A, Saranjam B, Ghaffari HR, Hazrati S, Poureshg Y, Fazlzadeh M (2019) Exposure and risk assessment of PAHs in indoor air of waterpipe cafés in Ardebil. Iran Build Environ 155:47-57

Shaikh H, Gaikwad H, Kadam A, Umrikar B (2020) Hydrogeochemical characterization of groundwater from semiarid region of western India for drinking and agricultural purposes with special reference to water quality index and potential health risks assessment. Appl Water Sci 10:204. https://doi.org/10.1007/ s13201-020-01287-z

Saleh TA, Tuzen M, Sarı A (2018) Polyamide magnetic palygorskite for the simultaneous removal of $\mathrm{Hg}$ (II) and methyl mercury; with factorial design analysis. J Environ Manage 211:323-333

Sappa G, Ergul S, Ferranti F (2014) Geochemical modeling and multivariate statistical evaluation of trace elements in arsenic contaminated groundwater systems of viterbo area, (Central Italy). Springerplus 3:1-19

Sehgal M, Garg A, Suresh R, Dagar P (2012) Heavy metal contamination in the Delhi segment of Yamuna basin. Environ Monit Assess 184(2):1181-1196. https://doi.org/10.1007/s10661-011-2031-9

Selvam S, Singaraja C, Venkatramanan S, Chung SY (2018) Geochemical appraisal of groundwater quality in Ottapidaram Taluk, Thoothukudi District, Tamil Nadu using graphical and numerical method. J Geol Soc India 92:313-320. https://doi.org/10.1007/ s12594-018-1013-8

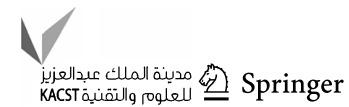


Selvam S, Venkatramanan S, Singaraja C (2015) A GIS-based assessment of water quality pollution indices for heavy metal contamination in Tuticorin Corporation Tamilnadu. India Arab J Geosci. https://doi.org/10.1007/s12517-015-1968-3

Selvam S, Venkatramanan S, Chung SY, Singaraja C (2016) Identification of groundwater contamination sources in Dindugal district of Tamil Nadu, India using GIS and multivariate statistical analyses. Arab Jour Geosci 9:407. https://doi.org/10.1007/ s12517-016-2417-7

Selvam S, Venkatramanan S, Sivasubramanian P, Chung SY, Singaraja C (2017) Geochemical characteristics and evaluation of minor and trace elements pollution in groundwater of Tuticorin City, Tamil Nadu, India using geospatial techniques. Jour Geol Soc India 90(1):62-68

Severini MDF, Carbone ME, Villagran DM, Marcovecchio JE (2018) Toxic metals in a highly urbanized industry-impacted estuary (Bahia Blanca Estuary, Argentina): spatio-temporal analysis based on GIS. Environmental Earth Sciences 77:393-411

Shan Y, Tysklind M, Hao F, Ouyang W, Chen S, Lin C (2013) Identification of sources of heavy metals in agricultural soils using multivariate analysis and GIS. J Soils Sediments 13:720-729

Shen F, Liao R, Ali A, Mahar A, Guo D, Li R (2017) Spatial distribution and risk assessment of heavy metals in soil near a $\mathrm{Pb} / \mathrm{Zn}$ smelter in Feng County, China. Ecotoxicol Environ Saf 139:254-262

Singaraja C, Chidambaram S, Srinivasamoorthy K, Anandhan P, Selvam S (2015) A study on assessment of credible sources of heavy metal pollution vulnerability in groundwater of thoothukudi districts Tamilnadu. India Water Qual Expo Health. https://doi.org/ 10.1007/s 12403015-0162-x

Srinivasamoorthy K, Nanthakumar C, Vasanthavigar M, Vijayaraghavan K, Rajivgandhi R, Chidambaram S, Anandhan P, Manivannan R, Vasudevan S (2009) Groundwater quality assessment from a hard rock terrain, Salem district of Tamilnadu, India. Arab J Geosci. doi:https://doi.org/10.1007/s12517-009-0076-7

Suresh M, Gurugnanam B, Vasudevan S, Dharanirajan K, Jawahar Raj N (2010) Drinking and irrigational feasibility of groundwater, GIS spatial mapping in upper Thirumanimuthar Sub-basin, Cauvery River, Tamil Nadu. J Geol Soc India 75:518-526

Tiwari AK, De Maio M, Singh PK, Mahato MK (2015) Evaluation of surface water quality by using GIS and a heavy metal pollution index (HPI) model in a coal mining area, India. Bull Environ Contam Toxicol 95(3):304-310

Varol M (2019) Arsenic and trace metals in a large reservoir: Seasonal and spatial variations, source identification and risk assessment for both residential and recreational users. Chemosphere 228:1-8

Venkatramanan S, Chung SY, Kim TH, Prasanna MV, Hamm SY (2014) Assessment and distribution of metals contamination in groundwater: a case study of Busan city, Korea. Water Qual Expo Health 7:219-225. https://doi.org/10.1007/s12403-014-0142-6

Verma OP, Khanan B, Shukla S (2012) Determination of physicochemical characteristics of four canals of Allahabad region and its suitability for irrigation. Adv Appl Sci Res 3(3):1531-1537
Vetrimurugan E, Brindha K, Elango L (2017) Osman Muzi Ndwandwe (2017) Human exposure risk to heavy metals through groundwater used for drinking in an intensively irrigated river delta. Appl Water Sci 7:3267-3280. https://doi.org/10.1007/s13201-016-0472-6

Vetrimurugan E, Elango L, Rajmohan N (2013) Sources of contaminants and groundwater quality in the coastal part of a river delta. Int J Environ Sci Technol 10:473-486

Vijay R, Khobragade P, Mohapatra PK (2011) Assessment of groundwater quality in Puri City, India: an impact of anthropogenic activities. Environ Monit Assess 177:409-418. https://doi.org/ 10.1007/s10661-010-1643-9

Wagh VM, Panaskar DB, Mukate SV, Gaikwad SK, Muley AA, Varade AM, (2019). Health risk assessment of heavy metal contamination in groundwater of Kadava River Basin, Nashik, India. Model Earth Syst Environ. Doi: https://doi.org/10.1007/ s40808-018-0496-z

Wang G, Zhang S, Xiao L, Zhong Q, Li L, Xu G (2017) Heavy metals in soils from a typical industrial area in sichuan, china: spatial distribution, source identification, and ecological risk assessment. Environ Sci Pollut Res 24:16618-16630

World Health Organization (2017) Guidelines for drinking-water quality. Fourth edition Incorporating the first addendum. Pp 1-631

Wu J, Sun Z (2016) Evaluation of shallow groundwater contamination and associated human health risk in an Alluvial Plain impacted by agricultural and industrial activities, Mid-west China. Expo 8:311-329

Xie Y, Chen T-B, Lei M, Yang J, Guo Q-J, Song B, Zhou X-Y (2011) Spatial distribution of soil heavy metal pollution estimated by different interpolation methods: accuracy and uncertainty analysis. Chemosphere 82:468-476

Yousefi M, Dehghani MH, Nasab SM, Taghavimanesh V, Nazmara S, Mohammadi AA (2018) Data on trend changes of drinking groundwater resources quality: a case study in Abhar. Data Brief 17:424-430

Zahir Hussain A, Mohamed Sheriff KM (2013) Status of heavy metal concentrations in groundwater samples situated in and around on the bank of Cooum river at Chennai city, Tamil Nadu. J Chem Pharm Res 5(3):73-77

Zamani AA, Yaftian MR, Parizanganeh A (2015) Statistical evaluation of topsoil heavy metal pollution around a lead and zinc production plant in Zanjan province. Iran Caspian J Environ Sci 13(4):349-361

Zhou JM, Jiang ZC, Xu GL (2019) Water quality analysis and health risk assessment for groundwater at Xiangshui, Chongzuo. Environ Sci 40(06):2675-2685. https://doi.org/10.13227/j.hjkx.201810234

Publisher's Note Springer Nature remains neutral with regard to jurisdictional claims in published maps and institutional affiliations 